\title{
Kelime Tanıma Envanteri Tasarımı ve Geliştirilmesi: Geçerlik ve Güvenirlik Çalışması*
}

\section{Design and Development of Word Recognition Inventory: Validity and Reliability Study}

\author{
Ayşegül AVŞAR TUNCAY**, Hakan DEDEOĞLU***
}

\begin{abstract}
Öz: Okumayı anlamlandırmanın ilk aşaması kelime tanımadır. Öğrenci, okuma metninde geçen kelimeleri tanırsa okuma onun için anlamlı hâle gelecektir. İlkokullarda öğrenciler farklı kelime tanıma düzeylerine sahip olmalarına rağmen aynı okuma parçalarını okumaktadırlar. $\mathrm{Bu}$ da okuma değerlendirme çalışmalarında öğrenciler arasındaki bireysel farklılıkları dikkate almayıp grupla değerlendirmenin yapılmasına neden olmaktadır. Bu araştırmada öğrencilerin kelime tanıma düzeylerinin belirlenmesi ve okuma parçalarının öğrencilerin düzeylerine göre seçilmesi açısından katkı sağlayacak bir aracın geliştirilmesi amaçlanmıştır. Bireysel bir değerlendirme aracı olarak tasarlanan envanterlerden Kelime Tanıma Envanteri-1'de (KTE-1) yer alan kelimeler öğrencilerin ilkokuma yazma sürecinde karşılaştıkları 6 seviye ses grubundan oluşan kelimelerden; Kelime Tanıma Envanteri-2'de (KTE-2) yer alan kelimeler ise ders kitaplarında geçen ve sınıf içi uygulamalarında öğrendikleri kelimelerden oluşmuştur. Tasarım ve geliştirme araştırma modelinin Tip 1 geliştirme araştırması türü kullanılarak yapılan araştırmanın çalışma grubunu uygun örnekleme yöntemiyle seçilmiş toplam 85 (\%52 kadın, \%48 erkek) ilkokul birinci sınıf öğrencisi oluşturmaktadır. Kelimelerin uygunluğu için içerik geçerliğine bakılmış, iç ve dış geçerliğine olası etki eden etkenlere yönelik önlemler alınmıştır. İç tutarlıklarının güvenirliğini ortaya koymak için KTE-1 ve KTE-2'nin güvenirlik katsayısı hesaplaması yapılmış; KTE-1'in tüm listelerinin Cronbach Alpha güvenirlik katsayısının .986; KTE-2'nin ise .970 olduğu sonucuna ulaşılmıştır. Sonuçlar, KTE-1 ve KTE2'nin geçerlik ve güvenirliğinin yüksek düzeyde olduğunu ortaya koyması, hata türü ve kelime türü arasında yüksek düzeyde ilişki bulunması, kelimeyi doğru okuma ve okuma hızları arasında doğru orantı olması ve tüm bu özelliklerin her iki envanterde de tutarlılık göstermesi envanterlerin iyi bir ölçme aracı olma özelliğine sahip olduğunu göstermektedir. KTE uygulanması sonucunda, öğrencilerin kelime tanıma düzeyleri belirlenerek kelime tanıma becerilerinin değerlendirilmesine ve bireysel ihtiyaçlarına uygun olan okuma çalışmaları yapılmasına katkı sağlayacağı düşünülmektedir.
\end{abstract}

Anahtar Kelimeler: Kelime tanıma, kelime tanımayı değerlendirme, kelime tanıma envanteri, geçerlik, güvenirlik

\begin{abstract}
The first stage of making sense of reading is Word recognition. If students recognise the words in a reading text, reading will become meaningful for them. Although students are at different levels of Word recognition at primary school, they read the same reading passages- which results in ignoring the individual differences between students and in making assessment in groups. This study aims to develop an instrument which will contribute to determining students' levels of word recognition and to selecting reading texts according to their levels. Of the inventories which were designed as individual assessment instruments, Word Recognition Inventory-1 (WRI-1) contained the vocabulary items of 6 level of vocal groups that students encountered in the process of primary literacy whereas Word Recognition Inventory2 (WRI-2) contained the vocabulary items they encountered in text books and they learned in in-class applications. The study group of this study, which is conducted in Type 1 development research of design and development research model, was composed of 85 primary school first graders (52\% girls and $48 \%$ boys) who were chosen in convenience sampling method. Content validity was checked for the convenience
\end{abstract}

\footnotetext{
* Bu makale, ilk yazarın ikinci yazar danışmanlığında hazırladığı ve 13.12.2017 tarihinde tamamlanan "İlkokul birinci sınıf öğrencilerine yönelik bir kelime tanıma envanteri tasarım ve geliştirme çalışması" isimli doktora tezinin bir kismidır.

** Dr. Öğr. Üyesi, Mersin Üniversitesi Eğitim Fakültesi, Mersin-Türkiye, ORCID: 0000-0002-0520-1747, e-posta aysegulaat@mersin.edu.tr

*** Doç. Dr., Hacettepe Üniversitesi, Eğitim Fakültesi, Ankara-Türkiye, ORCID: 00000003-2436-7010, e-posta: dede@hacettepe.edu.tr
} 
of the words, and precautions were taken for factors probable to influence internal and external validity. The reliability coefficients for WRI-1 and WRI-2 were calculated to exhibit the reliability of internal consistency, and Cronbach's Alpha reliability coefficient was found to be .986 for all the lists of WRI-1 and .970 for all the lists of WRI-2. The fact that the results showed WRI-1 and WRI-2 had high validity and reliability, that there were high correlations between error types and word types, that there was direct proportion between reading accurately and reading speed and that all those properties were consistent in both inventories demonstrated that the inventories were measurement tools of good quality. The WRI is thought to make contributions to determining students' levels of word recognition and thus evaluating their word recognition skills and to doing reading activities suitable to their individual needs.

Keywords: Word recognition, word recognition evaluation, word recognition inventory, validity, reliability

\section{Giriş}

İnsanlar kelimeler yoluyla iletişim kurar ve kelimeler sayesinde anlama anlatma etkinliklerini sürdürür. Hayatın ilk yıllarında sözel olarak gerçekleşen kelime anlama ve anlatma gibi kelime tanıma etkinlikleri dinleme ve konuşma yoluyla gerçekleşir. Okul hayatına başlayınca dinleme ve konuşmaya ek olarak okuma ve yazma yoluyla kelime anlama, anlatma ve tanıma etkinlikleri sürdürülür. "Yazılı bir kelime harf, hece, telaffuz gibi çeşitli ipuçlarından tanınmaktadır. Kelime tanıma, öğrencinin zihinsel sözlüğünü kullanarak kelimenin anlamını belirlemesi sonucu gerçekleşmektedir" (MEB, 2009, s. 16). "Kelime tanıma, verilen kelimeyi doğru bir şekilde seslendirmektir. Kelime ayırt etme ise kelimeyi hem doğru bir şekilde seslendirme hem de anlamını bilmektir. Kelime ayırt etme, kelime tanımayı kapsar. Kelime tanımayı, anlamı taşıyan araç; anlamı ise aracın taşıdığ mesaj olarak düşünebiliriz." (Akyol, 2012, s. 198). Dolayısıyla verilmek istenen mesajı anlayabilmek için öncelikle anlamı taşıyan aracın öğrenilmesi gerekmektedir.

Sözlü ve yazılı olmak üzere iki tür kelime tanıma söz konusudur (Güneş, 2013, s. 229230). Okul öncesi dönemde çocukların sözlü kelime tanımaları dinleme ve konuşma yoluyla olur. Çocukların erken yaşlarda çok sayıda kelime öğrenmeleri ilk okuma yazma öğretimi sürecinde okuma başarısını doğrudan etkilemektedir (Hart ve Risley, 2003). Yazılı kelime tanıma ise; çocuğun okuma yazma öğrenme sürecinde cümle ve metni düzgün bir ifadeyle ve belirli çabuklukta okuma, yani akıcı okumayı getirmektedir. Yazılı kelimeleri tanıma becerisi okuma ve yazma çalışmalarıyla gelişir. Çocuk okula başlayıncaya kadar anlamını bildiği kelimelerin hecelere ve harflere ayrıldığını sözlü kelime tanıma yoluyla öğrenemez. Bunun için yazı yazmayı öğrenmesi gerekmektedir. Çocuk ilkokul birinci sınıfa başladığında anlamını bildiği ve günlük hayatında çokça kullandığı kelimeleri oluşturan heceleri ve harfleri öğrenmeye başlar. Çocuk için daha önceki yaşantısında duyduğu kelimeleri yazılı olarak görmek, kelimeyi anlamlandırmasını kolaylaştıracaktır (Avşar Tuncay, 2017). Çocuğun kelimeyi anlamlandırması, cümleyi ve sonrasında metni anlamlandırmasını sağlayacak, dolayısıyla okuma akıcı hale gelecektir.

Okuma ve anlamada hangi düzeyde olduğunu tespit etmek ve hataları etkili bir şekilde belirleyip düzeltmek amaciyla değerlendirmeye ihtiyaç duyulmuştur. Bu ihtiyaca bağlı olarak geleneksel ve alternatif okuma değerlendirme uygulamaları kullanılmaya başlanmıştır. (Akyol, 2012; Akyol, Yıldırım, Ateş, Çetinkaya ve Rasinski, 2014; Göçer, 2013; Karasu, Girgin ve Uzuner, 2011). Alternatif okuma değerlendirme uygulamalarında, diğer beceri alanlarına ilişkin yapılan eğitsel ölçme ve değerlendirme uygulamalarında olduğu gibi, formel ve formel olmayan değerlendirme araçları kullanılabilir (Karasu, 2011, s. 20). Formel değerlendirme araçları, standartlaştırılmış bağıl testlere dayanan, puanlama ve sonuçların yorumlanması belirli kurallara göre yapılandırılmış değerlendirme araçlarıdır. Uygulayıcılar ve uygulama ortamları bakımından güvenilir olarak hazırlanan standartlaştırılmış bağıl testler, geçerliği ve güvenirliği olan ve ögrencinin performansını norm oluşturan gruptaki diğer bireylerin performansıyla karşılaştıran testlerdir. Formel olmayan değerlendirme araçları ise, öğrencinin performansını belli bir grubun gösterdiği beceriye göre değil, kendi performansına göre değerlendiren ve sonucunda kişinin okuma sürecine ilişkin bilgi veren değerlendirme araçlarıdır (Karasu, 2011; Kretschmer ve Kretschmer, 1978; McLoughlin ve Lewis, 2004; Richek, Caldwell, Jennings, Lerner, 2002; Uzuner, 2008). Öğrencinin okuma becerisindeki ilerlemeyi gözleyebilmek açısından formel ve formel olmayan ölçme araçlarının birlikte kullanılması önerilmektedir. Sınıf içi uygulamalarda 
öğretmenlere, öğrencilerini bir okuyucu olarak derinlemesine değerlendirme ve öğrencinin okuma becerisindeki güçlü ve zayıf yönleri kolaylıkla belirleyebilme imkânı sunan bu araçlar; ölçüt bağımlı testler, gözlem, görüşme, öz değerlendirme, ürün dosyası, formel olmayan okuma envanteri gibi değerlendirme araçlarından oluşabilir (Cooter ve Flynt, 1996; Karasu, 2011; McLoughlin ve Lewis, 2004; Uzuner, 2008). Akyol ve diğerlerine (2014) göre "Bir öğrencinin okuması sırasında kelime tanıma, okuma akıcılığı ve anlama olmak üzere üç kritik alanda performans düzeyi belirlenebilir. Okuma envanterlerinde yer alan değerlendirme etkinliklerinden elde edilen bilgilerle okumanın üç boyutu açısından öğrencinin zaman içerisinde ilerlemesi izlenebilir." Formel olmayan okuma envanterleri, öğrencinin güçlü ve zayıf yönlerini ortaya koyan özellikleri değerlendirebilmek amacıyla çeşitli düzeylerde ve farklı yazı türlerinde hazırlanan okuma metinleri ile kelime listelerini kapsar (Karasu, 2011, s. 25). Türkiye'de son yıllarda ilgi duyulan okuma değerlendirme çalışmalarında (Akyol ve diğerleri, 2014; Delimehmet Dada, 2017; Genç, 2016; Göçmenler, 2016; Karasu, 2011), değerlendirme aracı olarak genellikle okuma envanterinin kullanıldığı görülmektedir. Okuma envanterindeki metinleri okuyan öğrenci, eğer metinde geçen kelimeleri tanırsa, okuma onun için anlamlı hâle gelecektir. Bu nedenle çocuğa önce kelime tanıma düzeyini belirlemek üzere kelime tanıma envanteri, daha sonra da okumadaki durumunu belirlemek için okuma envanterini uygulamak daha doğru olacaktır.

\section{Kelime tanıma envanteri}

Kelime Tanıma Envanteri (KTE), öğrencinin kelime tanıma becerisini belirlemek ve değerlendirmek için yalın hâlde sunulmuş kelimeleri içeren listelerin yer aldığı formel olmayan bir değerlendirme aracıdır. Araştırmacılara göre (Akyol, 1998; Garnett, 2011; Goodman, 1967; Harris ve Sipay, 1990; Rayner, Foorman, Perfetti, Pesetsky ve Seidenberg, 2001; Snow, Burns ve Griffin, 1998; Torgesen, 1986), başarılı okuyucularda kelime tanıma özellikle küçük yaşlarda gelişir; 2. veya 3. sınıfta kelime tanıma becerileri otomatik hâle gelmektedir. Bu da kelime tanımada otomatikliğin erken oluşması için envanterin ilkokul 1 ve 2. sınıflarda kullanımının daha etkili olacağını göstermektedir.

İlkokul birinci sınıf öğrencileri için ses öğretimi gerçekleştiği anda heceler oluşturulmaya ve daha sonra hecelerden anlamlı kelimeler türetilmeye başlanır. Bazı sınıf öğretmenlerinin bu konuda, yani anlamlı kelime türetme konusunda hata yaptıkları, türettikleri kelimelerin anlamlı olmadığı gözlenmektedir. Öğrenci için anlamlı olmayan bir kelimeyi okumaya çalışmak oldukça zordur. Bu yüzden kelimelerin anlamlı olmasına dikkat etmek gerekir. Her ses grubunda yer alan seslerden kelime türetmek öğretmenler için de zor bir durumdur. Ellerinde yazılı bir kaynak olmaması onları anlamsız kelime türetmeye zorlamakta ve gereksiz zaman kaybına neden olmaktadır. Öğretmenler aynı zamanda kelime tanımada öğrenciyi değerlendirirken nasıl bir yol izleyeceğini neye göre değerlendirme yapacağını bilememektedir. Özellikle Türkçe Dersi Öğretim Programı'na göre, ses gruplarının belirli bir zaman diliminde verilmesi zorunluluğu öğretmen için de henüz o ses grubunu tam olarak öğrenememiş öğrenci için de sorun teşkil etmektedir. Öğretmen, öğrencinin öğrenip öğrenemediğini bilmeden ses grubunu tamamlayıp diğer ses grubunu işlemeye devam etmektedir. Ses grubuyla oluşturulan kelimeleri tam olarak okuyamadan diğer ses grubuna geçen öğrenci için bu sorun katlanarak devam etmektedir. Bu nedenle öğrencilerin her ses grubunu kendi içinde öğrenip öğrenemediğini ortaya koymak adına bireysel bir değerlendirme aracına ihtiyaç duyulmaktadır. KTE, ilkokul birinci sınıf öğrencilerinin okuma sürecinde karşı karşıya geldikleri her ses grubuna ait kelime listelerini içermesi bakımından, öğrencinin ses grubundaki seslerden oluşan kelimeyi tanımasına ve öğrencinin kelime tanıma becerisinin değerlendirilmesi için öğretmene yardımcı olacaktır.

\section{Kelime tanıma envanterinin geliştirilmesi}

Araştırmacı tarafından öğrencilerin kelime tanıma düzeylerini belirlemek amacıyla bir değerlendirme aracı geliştirilmiştir. Kelime Tanıma Envanteri geliştirilmeden önce yurt dışında kullanılan okuma envanterlerinde yer alan kelime tanıma listeleri incelenmiştir. İncelenen kelime tanıma listelerinde yer alan kelimelerin seçiminde farklı yollardan yararlanıldığı görülmüştür. Bunlardan bir tanesi Margaret La Pray ve Ramon Ross tarafından 1969 y1lında geliştirilmiş San 
Diego Quick Assessment (SDQA)'dır. SDQA'da yer alan listelerin sınıf düzeyine göre kategorize edilen kelimelerden oluşmasına dikkat edilmiş, kelimeler temel okuyucuların sözlüklerinden ve Thorndike ve Lorge (1944) tarafindan Teacher's Word Book of 30000 Words adli eserinde yer alan kelimelerden rastgele seçilmiştir. 1969 yılında yayımlanan The graded word list: Quick gauge of reading ability adlı makalelerinde yazarlar, dereceli kelime listelerini iki amaç için kullandıklarını belirtmişlerdir: bunlardan ilki okuma seviyesini belirlemek, ikincisi ise kelime analizinde okuma hatalarını tespit etmektir. Öğretmenler, öğrencileri okumalarına göre gruplandırmak veya öğrenciler için uygun okuma materyali seçmek için kelime listelerinden elde ettikleri bilgileri kullanabilir. Kelime listeleri, bu amaç için kullanıldığında olağanüstü derecede doğru sonuçlar vermektedir. Basic Reading Inventory'de yer alan kelime listeleri Edward William Dolch tarafından en çok kullanılan İngilizce kelimelerin yer aldığ 1 kelime listelerinden ve Educational Developmental Laboratories (EDL) Core Vocabulary Grades PrePrimer-12 ders kitaplarında bulunan kelimelerden oluşmaktadır. Bader Reading and Language Inventory'de kelime listelerinde yer alan kelimelerin seçiminde okuyucuların en sık kullandıkları kelimelerden ve alan çalışmalarından elde edilen kelimelerden yararlanıldığg görülmektedir. Ekwall/Shanker Informal Reading Inventory'de ise farklı olarak kelime seçiminde temel okuyucular ve Thorndike'in listesinden sözcükler rastgele seçilerek dereceli sözcük listeleri oluşturulmuştur (Pray ve Ross, 1969).

Bader Reading and Language Inventory'de yer alan kademeli kelime listelerinin her biri 10 kelimeden oluşurken, The Basic Reading Inventory, Analytical Reading Inventory, Ekwall/Shanker Informal Reading Inventory, Informal Reading Inventory, The Classroom Reading Inventory gibi okuma envanterlerinde yer alan kelime listeleri 20 kelimeden oluşmaktadır. Tüm envanterlerin kelime seçiminde basitten-karmaşığa, kolaydan-zora, kişinin yaşına ve sınıf seviyesine göre kademeli kelime seçimi yapıldığı görülmektedir. Sadece Bader Reading and Language Inventory'de yer alan kelimeler deneyimsel ve tematik listelerden oluşmaktadır. Envanterlerde yer alan listeler başlangıç öncesi düzeyden 12. seviyeye kadar kelimeler zorlaştırılarak verilmiştir. Bu envanterler ortaokul sonuna kadar kullanılabilen kelime listeleri içermektedir. The Basic Reading Inventory, The Classroom Reading Inventory, Informal Reading Inventory gibi bazı envanterlerde kelime listelerinin yanında kelime soruları da yer almaktadır.

İncelenen kelime listeleri sonrasında araştırmacılar tarafından geliştirilen Kelime Tanıma Envanteri-1 (KTE-1) ve Kelime Tanıma Envanteri-2 (KTE-2)'de yer alan kelimeler belirlenmiştir. Buna göre 6 seviye ses grubundan kelimeler türetilmiş ve KTE-1'e eklenmiştir. Türkiye Cumhuriyeti Milli Eğitim Bakanlığı tarafından ilkokullarda okutulması önerilen Türkçe, Hayat Bilgisi ve Matematik ders kitaplarında ve Karadağ'ın (2005) ilköğretim 1-5. sinıf öğrencilerinin sınıf düzeyine göre yaygın olarak kullandığı kelimelerden oluşan çalışmasında yer alan kelimelere de KTE-2'de yer verilmiştir. Envanterlerde yer alan kelimeler öğrencilerin geçmiş yaşantılarından elde ettikleri, bilgi ve yaşantılarında hâlâ var olan kelimelerden seçilmesi değerlendirmenin güvenirliğini etkileyen bir özelliktir (Roe ve Burns, 2007, s. 4) Bu nedenle KTE-1 ve KTE-2'de yer alan kelimeler öğrencilerin ders kitaplarında ve sınıf içi çalışmalarında bulunan ve günlük yaşamlarındaki konuşmalarında karşılaştıkları kelimelerden seçilmiştir. Kelime tanıma listelerinde yer alan kelimeler, öğrencinin kelime tanıma düzeylerini ve kelime kullanımını değerlendirmek için yalın hâlde sunulmuş, her bir listede bulunan kelimeler yaklaşık olarak eşit zorlukta kelimelerden seçilmiş, kelimelerin seçiminde harf-hece sayısı gibi biçimsel özellikler dikkate alınmış, her sınıf düzeyinde kullanılabilecek şekilde çeşitli seviyelerde kelime örneklerinden oluşturulmuştur. The Basic Reading Inventory, Analytical Reading Inventory, Ekwall/Shanker Informal Reading Inventory, Informal Reading Inventory, The Classroom Reading Inventory gibi okuma envanterlerinde yer alan kelime listelerinin 20 kelimeden oluştuğu görülmektedir. Bu çalışmada da okuyucunun kelime tanıma düzeyini belirlemek için her bir listede 20 kelimeye yer verilmiştir. Türkiye Cumhuriyeti Milli Eğitim Bakanlığ1, 2018-2019 eğitim öğretim yılında başlattığı yeni uygulamada okul zümre öğretmenlerinin kararıyla ilk okuma yazma öğretiminin dik temel harf ya da bitişik eğik harflerle yapılmasına karar vermiştir. Buna göre envanterler hem bitişik eğik yazıyla hem de dik temel yazıyla hazırlanmış, örgün 
eğitim süresince ilkokul birinci sınıf öğrencilerinin kelime tanıma becerisinin değerlendirilmesinde ve öğrencilerin bireysel ihtiyaçlarına uygun olarak ilk okuma yazma öğretim programının düzenlenmesinde kullanılması düşünülmüştür.

$\mathrm{Bu}$ çalışmanın amacı, ilkokul birinci sınıf öğrencilerinin kelime tanıma düzeylerini belirlemede sınıf öğretmenlerine yardımcı olacak kelime listelerinin geliştirilmesidir. Geliştirilen kelime listeleriyle ulaşılmak istenen hedefler şunlardır: (1) ilkokul birinci sınıf öğrencileri için anlamlı okumada çok önemli yere sahip olan kelime tanıma düzeylerini belirlemek, (2) okuma metinlerinin öğrencilerin düzeylerine göre seçilmesi açısından sınıf öğretmenlerine katkı sağlayacak geçerli ve güvenilir bir değerlendirme aracı geliştirmek ve (3) geliştirilen aracın uygulanabilirliğini ortaya koymaktır. Kelime Tanıma Envanteri'nin çıkış noktasını Amerika Birleşik Devletleri'nde (ABD) okuyucuları kitaplar, makaleler ve diğer seviyeli okuma kaynaklarıyla eşleştirmek için kullanılan Lexile diye adlandırılan bir eğitim aracı oluşturmaktadır. Öğrencinin okuma düzeyini belirlemek amacıyla kitaplara Lexile ölçeğinde puan verilmektedir. Düşük puanlar, kitaplar için daha kolay okunabilirlik ve okuyucular için daha düşük okuma düzeyi anlamına gelirken; yüksek puanlar, kitaplar için daha zor okunabilirlik ve okuyucular için daha yüksek okuma düzeyi anlamına gelir. ABD'de Lexile puanları, okuma programları ve değerlendirmeler yıllık olarak raporlanmaktadır. Böylece ABD öğrencileri her sene Lexile ölçüsü alır (Lexile, 2017). Lexile ölçüsünün önemli olduğu ve okuma seviyelerini bu ölçüyü dikkate alarak grupladıkları düşünüldüğünde öğrencilerinin Lexile düzeylerini ve okunabilirlik verilerini sağlamak için öğretmenlerin güvenecekleri bir değerlendirme aracı kullanmaları gerekmektedir. 2002 y1lı No Child Left Behind (NCLB) yasasının yanı sıra eyalet tarafindan zorunlu tutulan ve öğrenci başarısının değerlendirilmesine verilen önem, öğrencilerin bireysel ihtiyaçlarını karşılamak, kaliteli öğretimi planlamak ve uygulamak için öğretmenlerin öğrencilerin performanslarını izlemelerini gerekli k1lmaktadır (Monti, 2003; Paris ve Carpenter, 2003). Okuma envanterlerinin geliştirilme fikri, öğrencinin okuma düzeyini belirlemek için öğretmenin sınıf içerisinde bireysel değerlendirme aracına duyulan ihtiyaçtan kaynaklanmaktadır.

\section{Yöntem}

$\mathrm{Bu}$ araştırmada öğrencilerin kelime tanıma düzeylerini belirlemeye yönelik bir araç geliştirilmesi ve bu aracın uygulanabilirliğini ortaya koyması bakımından tasarım ve geliştirme araştırma modelinin Tip 1 geliştirme araştırması türü kullanılmıştır. "Yeni ürün, araç, model ve süreçlerin geliştirildiği ve geliştirilen ürünün denenerek uygulanabilirliğinin, etkililik ve verimliliğinin ortaya koyulduğu araştırmalar 'tasarım ve geliştirme araştırması (TGA)' olarak adlandırılmaktadır.” (Richey ve Klein, 2008; akt. Büyüköztürk, Kılıç-Çakmak, Akgün, Karadeniz ve Demirel (2016, s. 225). Tasarım ve geliştirme araştırmalarına özgü olan şey; uzun vadede eğitimi desteklemek için araçlar ve modeller geliştirmektir (McKenney ve Reeves, 2013, s. 139). Ürettiği bilgilere ek olarak, eğitimde tasarım ve geliştirme araştırmasının değeri, geliştirilen aracın eğitimde uygulanabilirliğini geliştirmesiyle ölçülür (Design-Based Research Collective, 2003, s. 5). Büyüköztürk ve diğerleri (2016) tasarım ve geliştirme araştırmalarını iki kategoride toplamış, Tip-1 ve Tip-2 şeklinde isimlendirmiştir. Tip-1 ürünler ve araçların geliştirilmesiyle ilgili araştırmalar, Tip-2 tasarım ve geliştirme modellerinin geliştirilmesiyle ilgili araştırmalardır. Tip-1 çalışması Ürün ve Araç Araştırması olarak da adlandırılır, amacı bir ürün veya araç geliştirmek veya test etmektir. Tip-1 türünde ürün ve araç geliştirme süreçleri üç aşamadan oluşur. Bunlar; analiz aşaması, ürün geliştirme aşaması, son ürünün değerlendirilme aşaması olarak tanımlanabilir (Mutlu, 2016, s. 54). Yeni ürün olarak tasarlanması düşünülen KTE-1 ve KTE2'nin tasarım ve geliştirme aşamalarının detaylı dokümantasyonunun olması, geçerliği ve güvenirliği test edilip uygulanabilirliğinin denendiği ve değerlendirildiği bu araştırmanın yapısı tasarım ve geliştirme araştırma modelinin Tip-1 Ürün ve Araç Araştırması türüne uygundur.

\section{Çalışma grubu}

Araştırmanın çalışma grubunu; uygun örnekleme yöntemiyle seçilmiş, Ankara ilinin Yenimahalle ilçesinde bulunan üç farklı devlet okulunda öğrenim görmekte olan toplam 85 ilkokul 1. sinıf öğrencisi oluşturmaktadır. Okulların seçiminde sosyo-ekonomik durumları göz önünde tutulmuş 
böylelikle çeşitlilik sağlanmıştır. Sosyo-ekonomik düzeyin seçilme amacı, aynı ortamlardan seçilmiş öğrencilerle yapıldığında kelime tanıma düzeylerinde herhangi bir fark çıkmayabileceğinden dolayı, öğrencilerin yaşadıkları çevrede karşılaştıkları kelimeleri okurken kelime tanıma düzeyleri arasında farklılık yaratmaktır. Araştırmaya katılan öğrencilerin demografik bilgileri incelendiğinde öğrencilerin 44'ünün kadın (\%51,8), 41'inin (\%48,2) erkek olduğu görülmektedir. Yaş değişkenine göre incelendiğinde araştırmaya katılan öğrencilerin 1 'nin $(\% 1,2)$ zorunlu olmayıp isteğe bağl1, veli dilekçesi ile kayıt yapılabilecek ay aralığı olan 65 aylık, 13'ünün $(\% 15,3)$ zorunlu, fakat doktor raporu ile kayıt olmayabileceği ay aralığı olan 6971 aylık, 71'inin $(\% 83,5)$ zorunlu kayıt ayları olan $72-85$ ay aralığında olduğu görülmektedir. Sosyo-ekonomik durum değişkenine göre öğrencilerin 23'ünün $(\% 27,1)$ üst seviyede sosyoekonomik duruma sahip A İlkokulunda, 34'ünün (\%40) orta seviyede sosyo-ekonomik duruma sahip B İlkokulunda, 28 'inin $(\% 32,9)$ alt seviyede sosyo-ekonomik duruma sahip C İlkokulunda olduğu görülmektedir. Okul öncesi eğitim alıp-almama değişkenine göre öğrencilerin 77'sinin $(\% 90,6)$ okul öncesi eğitim aldığ 1,8 'inin $(\% 9,4)$ okul öncesi eğitim almadığı görülmektedir. Okul öncesi eğitimi aldığı okul türü değişkenine göre araştırmaya katılan öğrencilerin 36 'sının $(\% 42,4)$ anaokuluna gittiği, 41'inin $(\% 48,2)$ hem kreş hem de anaokuluna gittiği, 8 'inin $(\% 9,4)$ ise okul öncesi eğitime hiç gitmediği görülmektedir.

\section{Veri toplama araçları}

$\mathrm{Bu}$ araştırmada öğrencilerin kelime tanıma düzeylerini belirlemek amacıyla araştırmacı tarafından geliştirilen KTE-1, KTE-2 ve Kelime Tanıma Çizelgesi veri toplama araçları olarak kullanılmıştır.

Kelime tanıma envanterleri: KTE-1'de Milli Eğitim Bakanlı̆ğ Talim Terbiye Kurulu Başkanlığı'nın 05.08.2015 tarih ve 71 sayılı kurul kararı ile kabul edilen İlkokul Türkçe Dersi Öğretim Programında yer alan ve 2016-2017 eğitim-öğretim y1lında kullanılan 6 seviye ses grubundan kelimeler türetilmiştir. KTE-2'de ise Milli Eğitim Bakanlığ 1 tarafından ilkokullarda okutulması önerilen Türkçe, Hayat Bilgisi ve Matematik ders kitaplarında yer alan kelimelere yer verilmiştir. Her iki envanterde de yer alan kelimeler öğrencilerin ders kitaplarında ve sınıf içi çalışmalarında bulunan ve günlük yaşamlarındaki konuşmalarında karşılaştıkları kelimelerden seçilmiştir. Bitişik eğik yazıyla hazırlanmış KTE-1'de her biri 20 kelimeden oluşan 64 tane, okunuşunu bilmese de ders kitaplarında yer alan ve sınıf içi uygulamalarında öğrendikleri kelimelerden oluşan ve dik temel yazıyla hazırlanmış KTE-2'de her biri 20 kelimeden oluşan 34 tane listeyle toplamda 98 liste oluşturulmuştur. Envanterlerde yer alan kelime listeleri her bir liste bir sayfada yer alacak şekilde düzenlenmiş ve kelimelerin puntosu 20 olarak belirlenmiştir. KTE'lerde yer alan kelimelerin; yalın hâlde sunulmasına, öğrencilerin yaşına, bilgi düzeyine ve sinıf seviyesine uygun farklı düzeylerde olmasına, 6 seviye ses grubundan oluşturulan ve ders kitaplarında yer alan kelimelerde yer alan hece sayısı, harf sayısı ve basitten karmaşığa doğru sıralanmasına, sözcük çeşitliliğinin benzer olmasına (orantılı isim, sıfat, fiil kullanımı gibi...), her bir listenin 20 kelimeden oluşmasına dikkat edilmiştir. 6 seviye ses grubundan ve ders kitaplarındaki kelimelerden oluşturulmuş envanterlerdeki kelime listelerinin ayrıntılı gösteriliş biçimi Tablo 1'de yer almaktadır.

Tablo 1.

KTE-1 ve KTE-2'de Yer Alan Kelime Listelerinin Sayılarına Göre Dağglımları

\begin{tabular}{lrrrr}
\hline Seviyeler & Ses Gruplar1 & KTE-1 Liste Sayıs1 & KTE-2 Liste Say1S1 & Toplam \\
\hline 1. Seviye & E, L, A, N & 1 & - & 1 \\
2. Seviye & I, T, O, B, U & 5 & - & 5 \\
3. Seviye & K, I, R, Ö, S, Ü & 12 & 5 & 17 \\
4. Seviye & M, D, Ş, Y, C, Z & 15 & 15 & 30 \\
5. Seviye & Ç, G, P, H & 16 & 8 & 24 \\
6. Seviye & F, V, Ğ, J & 15 & 6 & 21 \\
\hline Toplam & & 64 & 34 & 98 \\
\hline
\end{tabular}


Tablo 1 incelendiğinde KTE-1'in 1. Seviyesinde yer alan E, L, A, N ses grubundan 1 liste, 2. Seviyesinde yer alan İ, T, O, B, U ses grubundan 5 liste, 3. Seviyesinde yer alan K, I, R, Ö, S, Ü ses grubundan 12 liste, 4. Seviyesinde yer alan M, D, Ş, Y, C, Z ses grubundan 15 liste, 5. Seviyesinde yer alan Ç, G, P, H ses grubundan 16 liste, 6 . Seviyesinde yer alan F, V, Ğ, J ses grubundan 15 liste ile toplamda 64 listeden oluştuğu görülmektedir. KTE-2'nin 1 ve 2. Seviyesinde kelime listeleri bulunmamaktadır. Tüm sesli harflerin 3. Seviyede tamamlanmas1 sonucu ilkokullarda önerilen Hayat Bilgisi, Türkçe ve Matematik kitaplarında ilk konudan itibaren birçok kelime 3. Seviye ve sonraki seviyelerin ses gruplarıyla oluşturulabilecek kelimeleri içermektedir. Bu yüzden 3. Seviyeden itibaren liste oluşturulması tercih edilmiştir. KTE-2'nin 3. Seviyesinde yer alan K, I, R, Ö, S, Ü ses grubundan 5 liste, 4. Seviyesinde yer alan M, D, Ş, Y, C, Z ses grubundan 15 liste, 5. Seviyesinde yer alan Ç, G, P, H ses grubundan 8 liste, 6. Seviyesinde yer alan F, V, Ğ, J ses grubundan 6 liste ile toplamda 34 listeden oluştuğu görülmektedir. Buna göre envanterlerde yer alan toplam liste 98'dir.

Kelime Tanıma Çizelgesi: Kelime Tanıma Çizelgesi envanterlerin aksine öğrencilerin göremeyeceği, sadece uygulayıcıların kullanacağı şekilde tasarlanmış ölçme araçlarıdır. Öğrencilerin önünde sadece kelime listelerini okuyabilecekleri KTE-1 ve KTE-2 yer almaktadır. Uygulayıcının önünde ise, öğrencilerin envanterleri okuduğu sırada onların listelerinin aynısının yer aldığ1 ve öğrencilerin doğru/yanlış okumalarını kaydettikleri Kelime Tanıma Çizelgesi yer almaktadır. Kelime Tanıma Çizelgesi'nde öğrencilerin doğru okudukları kelimeler “ $\sqrt{ }$ " işaretiyle, hatalı okudukları kelimeler de okudukları şekilde kaydedilir. Öğrencilerin yaptığı okuma hataları kısaca şu şekilde tanımlanmaktadır:

Yanlış Telaffuz: Öğrenciler kelimeyi telaffuz etmeye çalışır, ancak gerçek bir kelimeden ziyade anlamsız bir kelime üretirler. Örnek: Yanlış/Yamlış

Yerine Koyma: Öğrenciler okunacak kelime yerine başka bir kelime okurlar. Örnek: $\mathrm{Ev} / \mathrm{Av}$

Ekleme Yapma: Öğrenciler kelime içinde yer almayan harf veya harfler ekler. Örnek: Kask/Kasık

Çıkarma Yapma: Öğrenciler kelime içinde bir heceyi veya sesi atlar. Örnek: İllet/İlet

Tersine Çevirme: Öğrenciler kelimede yer alan hece veya seslerin yerini değiştirir. Örnek: Abant/Abnat

Tekrarlama: Öğrenciler kelimeyi doğru okur fakat geri dönüp kelime içinde yer alan hece veya sesleri bir daha okur. Örnek: Lala/Lalala

Öğretmenin Söylemesi: Öğrenciler kelimeyi beklenen sürede okuyamadıklarında uygulayıcının kelimeyi söylemesi şeklinde açıklanmaktadır.

$\mathrm{Bu}$ çizelgede uygulayıcının öğrencinin okuduğu doğru kelimeleri belirtebileceği doğru sayısı, yanlış okuduğu kelimeleri belirtebileceği yanlış sayısı ve okuma sürelerini belirtebileceği alan bulunmaktadır.

\section{Geçerlik}

Bireylerin bir alandaki öğrenme düzeylerini (performanslarını) ölçmeyi hedefleyen başarı testleri için belirlenmesi gereken geçerlik çeşidi içerik geçerliğidir (Kırcaali-İftar, 1999, s. 17). Öğrencilerin kelime tanıma becerilerini değerlendirmeyi amaçlayan bu çalışmada da içerik geçerliği belirlenmiştir. İçerik geçerliği için; seçilen kelimelerin öğrencilerin yaşı, bilgi düzeyi ve sınıf seviyesine uygunluğu, listelerde yer alan sözcük çeşitliliğinin benzerliği (orantılı isim, sıfat, fiil kullanımı gibi...), 6 seviye ses grubundan oluşturulan ve ders kitaplarında yer alan kelimelerde yer alan hece sayısı, harf sayısı ve basitten karmaşığa doğru sıralanışına bakılmıştır. Kelimelerin seçimi ve değerlendirme formunun düzenlenmesinde Hacettepe Üniversitesi Eğitim Fakültesi'nde yer alan iki öğretim elemanından oluşan uzman kişilerin görüşleri temele alınmıştır. Thiagarajan, Semmel ve Semmel (1974), geliştirme aşamasında öğretim metodunu, materyalini ve öğretimde kullanılan dili daha etkili hâle getirmek adına çeşitli uzmanlık alanlarındaki profesyonellerden bu aşamada yardım alınmasının önemine vurgu yapmışlardır (Özden ve Durdu, 2016, s. 62). 
Araştırmanın iç geçerliğine olası etki eden tehditlere yönelik bir takım önlemler alınmış, bunlar sırasıyla verilmiştir. Araştırmaya katılan öğrencilere "Öğrenci Bilgi Formu" uygulanarak çeşitli değişkenler açısından (cinsiyet, sosyo-ekonomik durum, ailelerin eğitim durumu, ailelerin meslek durumu... gibi) benzerlikler ortaya konulmaya çalışılmıştır. Katılımcı kaybının, uygulama sırasında diğer katılımcılarla aynı listeleri okuyamama durumunu ve araştırmanın sonuçları üzerindeki etkisini en aza indirebilmek için, çalışma sonunda listeleri tamamlayamayan, başka bir okula kaydını aldıran, sık sık hastalandığı için listeleri eksik okuyan öğrenciler belirlenerek araştırmanın kapsamı dışında tutulmuştur. Öğrencilerde beklenti etkisi yaratmak adına araştırmanın hangi aşamasında kaç liste okuyacakları hakkında bilgi verilmemiştir. Veri toplama araçlarından kaynaklı tehditlerin önüne geçebilmek için tüm katılımcılara aynı ölçme aracı aynı zaman diliminde ve aynı kişiler tarafından uygulanmıştır. Ayrıca tüm öğrencilere okumaları sırasında eşit bekleme süresi tanınmıştır. Mekâna bağlı olarak ortaya çıkabilecek iç geçerlik tehditlerini engelleyebilmek için tüm sınıflarda veriler aynı ortamda toplanmıştır. B ilkokulu ve C ilkokulundaki veriler okulun kütüphanesinde, A ilkokulundaki veriler ise boş olduğu için müdür yardımcısının odasında toplanmıştır.

Araştırmanın diş geçerliğini tehdit eden örnekleme (temsil edebilme) etkisi ise; araştırmanın çalışma grubunun yapısı nedeniyle sınırlı bir genelleme söz konusudur. Çalışma devlet okullarının sosyo-ekonomik durumu farklı düzeylerde olan üç ilkokulunun toplamda dört tane birinci sınıfında öğrenim görmekte olan 85 öğrencisiyle gerçekleştirilmiştir. Elde edilen sonuçlar sadece benzer özelliklere sahip gruplar için genellenebilir.

\section{Güvenirlik}

Güvenirlik, bir çalışmanın veya deneyin benzer sonuçlar ile tekrarlanabilirliğinin derecesidir (Johnson, 2014, s. 111). Güvenirlik aynı şekilde yapılan araştırmanın aynı sonucu vermesi olarak anlaşılsa da Kirk ve Miller (1986) bunu yanlış yönlendirme olarak ifade etmişler ve nitel araştırmalardaki ölçüm ve ifadelerin nadiren sabit kaldığını savunarak farklı araçları kullanarak tutarlı sonuç elde etmenin bir kriter olamayacağından bahsetmişlerdir. Yapılan araştırmayı, varsayımları, kısıtlamaları, katılımcı ile olan ilişkileri ve tüm araştırma adımlarını iyi açıklamak gereklidir (Koç, 2016, s. 154).

Buna göre araştırmanın varsayımları, kısıtlamaları, veri toplama araçları, veri toplama araçlarının uygulanışı, katılımcılarla olan ilişki, öğretmenlerle olan ilişki ve araştırmaya dair tüm adımlar ayrıntılı şekilde açıklanmıştır. Bu tarz detaylandırma araştırmanın güvenirliğini arttırır. Koç'a (2016) göre; "Notların standardize edilmesi, eğer birkaç araştırmacı rol oynamışsa veri toplamada güvenirliği arttırır." (s. 154). Veri toplama sırasında kelime listelerinin birkaç araştırmacı tarafından toplanması ve standardize edilmiş bir değerlendirme çizelgesinin hazırlanmış olması da güvenirliği arttıran unsurlardandır. Uygulamanın planlandığ 1 şekilde yapılıp yapılmadığı, aynı zamanda değerlendirme aşamasına gelindiğinde kelime tanıma çizelgesinde yer alan hatalı okumalardaki belirgin olmayan yanlışların analizinde uzmanlara danışılıp ortak bir karar sonucu yanlışın ne tür bir yanlış olduğunun belirlenmesi de değerlendiriciler arası güvenirliğe örnek olarak verilebilmektedir.

İç tutarlıklarının güvenirliğini ortaya koymak için KTE-1 ve KTE-2'nin güvenirlik katsayısı hesaplaması yapılmıştır. Bu tür güvenirlik katsayısı hesaplamalarından KR-20 ya da Cronbach Alpha elde edilen test puanları arasındaki iç tutarlığı incelemek amacıyla kullanılır. Test maddelerine verilecek cevapların doğru/yanlış, evet/hayır gibi iki seçenekli olması durumunda KR-20, pek çok kişilik testlerinde olduğu gibi üç veya daha fazla olması durumunda Cronbach tarafından geliştirilmiş olan alfa katsayısı kullanılır (Büyüköztürk, 2007, s. 170-171). KTE-1 ve KTE-2'de yer alan kelime listelerini okuyan öğrencilerin verdikleri cevaplar doğru/yanlış olarak kodlansa da, hataların birden fazla kod (yanlış telaffuz, yerine koyma, ekleme yapma, ses düşmesi, tersine çevirme, tekrarlama ve öğretmenin söylemesi) içermesinden dolayı kelime sayılarına ilişkin güvenirlik katsayıları hesaplanırken Cronbach Alpha güvenirlik katsayısı kullanılmıştır. Buna göre Tablo 2'de KTE-1'in kelime listelerinin kelime sayılarına ilişkin güvenirlik katsayıları gösterilmiştir. 
Tablo 2.

Kelime Tanıma Envanteri-1'in Kelime Listelerinin Kelime Sayılarına İlişkin Güvenirlik Değerleri

\begin{tabular}{lrrr}
\hline Seviye & Liste SayıS1 & Kelime Sayıs & Alpha Güvenirlik Katsay1S1 \\
\hline 1. Seviye & 1 & 20 & .864 \\
2. Seviye & 5 & 100 & .923 \\
3. Seviye & 12 & 240 & .953 \\
4. Seviye & 15 & 300 & .955 \\
5. Seviye & 16 & 320 & .941 \\
6. Seviye & 15 & 300 & .963 \\
\hline Toplam & 64 & 1280 & .986 \\
\hline
\end{tabular}

Tablo 2 incelendiğinde seviyelerin Cronbach Alpha güvenirlik katsayıları .864 ve .963 arasında değişmektedir. KTE-1'in tüm listelerinin Cronbach Alpha güvenirlik katsayısının ise .986 olduğu görülmektedir. Tablo 3'de ise KTE-2'nin kelime listelerinin kelime sayılarına ilişkin güvenirlik katsayıları gösterilmiştir.

Tablo 3.

KTE-2'nin Kelime Listelerinin Kelime Sayılarına İlişkin Güvenirlik Değerleri

\begin{tabular}{lrrrr}
\hline Seviye & Liste Sayıs1 & Kelime Say1s1 & Alpha Güvenirlik Katsay1s1 \\
\hline 1. Seviye & - & - & - \\
2. Seviye & - & - & - \\
3. Seviye & 5 & 100 & .877 \\
4. Seviye & 15 & 300 & .957 \\
5. Seviye & 8 & 160 & .871 \\
6. Seviye & 6 & 120 & .844 \\
\hline Toplam & 34 & 680 & .970 \\
\hline
\end{tabular}

Tablo 3 incelendiğinde seviyelerin Cronbach Alpha güvenirlik katsayıları .844 ve .957 arasında değişmektedir. KTE-2'nin tüm listelerinin Cronbach Alpha güvenirlik katsayısının ise .970 olduğu görülmektedir. Buna göre hesaplanan güvenirlik katsayısılarının .70 ve daha yüksek olması envanterlerin güvenirliği için genel olarak yeterli görülmektedir (Büyüköztürk, 2007, s. 171).

Geçerlik güvenirliğine bakılan envanterin işlerliğini test etmek için geliştirilen ölçme araçlarının uygulanacağı grup belirlenerek pilot uygulama yapılmıştır. Pilot uygulaması için, tasarlanan KTE-1 ve KTE-2'nin ve uygulama planının etkililiğini sınamak amacıyla araştırma grubunda bulunmayan 10 öğrenci ile çalışılmıştır. Pilot çalışmada her bir öğrenci kelime listelerini okumuş, okumaları süresince araştırmacı tarafından okuma hataları belirlenmiş ve "Kelime Tanıma Çizelgesi”ne kaydedilmiştir. Pilot uygulaması sırasında geliştirilen araçlarda ve uygulamada herhangi bir sorunla karşılaşılmamıştır. Pilot çalışma sonrasında araştırmanın uygulanabilirliği hakkında öğretmenlerden ve uzmanlardan dönüt alınarak envanterlerde yar alan kelimeler üzerinde gerekli düzenlemeler yapılmıştır.

\section{İşlem}

Ankara ili Yenimahalle ilçesindeki farklı sosyo-ekonomik duruma sahip (üst-orta-alt) uygun örnekleme yöntemiyle seçilen üç okulun dört sınıfında okuyan birinci sınıf öğrencilerine 20162017 eğitim-öğretim yılı boyunca uygulamalar yapılmıştır. İlk olarak öğrencilerin öğrendikleri her ses grubundan sonra bitişik eğik yazıyla hazırlanan KTE-1, daha sonra da dik temel yazıyla hazırlanan KTE-2 uygulanmıştır. Araştırmacının uygulama yaptı̆̆ okullardan B ilkokulu, birinci sinıflarda dâhil tüm öğrencilere tüm gün eğitim vermekte olup, A ilkokulu ve C ilkokulu ise birinci sınıfları öğlenci olarak belirlemiştir. 19 Eylül 2016 okulların açılmasıyla birlikte öğretmenlerle görüşülmüş, sınıf hakkında bilgiler alınmış, uygulamaları yapmak için 
öğretmenlerle iletişimde kalınmıştır. Uygulamalar tam anlamıyla 2 Kasım 2016 tarihinde başlamış, 3 Mart 2017 tarihinde bitmiştir. 19 Eylül 2016 tarihinde okulların açılmasıyla birlikte öğretmenlerle çalışmanın amacı, kapsamı, sürecin nasıl işleyeceği, uygulamanın nerede ve nasıl yapılacağı hakkında bilgiler verilmeye başlanmıştır.

Uygulama sırasında öğrencinin önünde KTE, uygulayıcının önünde de Kelime Tanıma Çizelgesi yer almaktadır. Uygulayıcı öğrenciyi sınıfından kendisi alıp, uygulamanın yapıldığ mekâna getirmiştir. Bir masada uygulayıcı ile öğrenci, öğrencinin onun işaretlemelerini göremeyeceği şekilde karşı karşıya oturmuşlardır. Birinci sınıf öğrencileri, özellikle okuma düzeyi zayıf olanlar, bir yabancının yanında bazen okumak istemeyebilir. Bu sebeple uygulayıcı öğrencinin çekinmemesi, yanında rahat etmesi ve onun yanında okuması için öğrenciyi cesaretlendirmiş, okumaya geçmeden önce öğrenciyle kısa kısa sohbet etmiştir. Okumaya geçtiklerinde ise kelimeleri tek tek, sırayla okumasını istemiş, öğrenci listedeki kelimeleri okurken her bir kelime arasında ilk uygulamalarda süre kısitlaması yokken daha sonra en fazla 10 saniye bekleyip sıradaki kelimeye geçmesi cesaretlendirilmiştir. Öğrencinin okuduğu her liste için süre tutulmuştur. Öğrenci listedeki kelimeleri okurken araştırmacı Kelime Tanıma Çizelgesi'nde öğrencinin okuduğu kelimeleri doğru/yanlış diye kodlamaktadır. Uygulamalar sırasında öğrenci sıkılmış, okumak istememiş, üşümüş, sicaklamış, konuşmak istemişse araştırmacı süreyi durdurup öğrencinin yapmak istediği şeyi yapmasını sağlayıp daha sonra devam etmiştir. Araştırmacının KTE uygulanmasında izlediği aşamalar şu şekilde sıralanabilir.

1. Uygulamaya başlangıç düzeyinde yer alan kelimelerin okunmasıyla başlanmakta, öğrenciye her kelimeyi zor olsa bile mutlaka okuması söylenmektedir. Doğru cevap verirse, uygulayıc1 kendi test belgesindeki kelimelerin üzerine $\sqrt{ }$ işareti koymaktadır.

2. Öğrenci bir kelimeyi hatalı okuyup telaffuzunu düzeltmezse, uygulayıcı çocuğun yanlışını kendi test belgesine öğrencinin okuduğu şekilde kaydetmekte ve ödün verilmemektedir.

3. Öğrenci bir kelimeyi hatalı okuyup, ancak daha sonraki kelimeye devam etmeden önce hatasını düzeltirse, uygulayıcı Kelime Tanıma Çizelgesi'ne kaydetmekte ve yanlış okuduktan sonra düzelttiğini belirtmekte ve kayıt formuna $\sqrt{ }$ işaretini koymaktadır. Bu kelime için ödün verilebilir.

4. Öğrenci eğer bir kelimeyi doğru okumadan önce birkaç defa hatalı okursa, hiçbir ödün verilmemektedir. Uygulayıcı, daha sonra yapılacak analizler için tüm hatalı yanıtları kaydetmektedir.

5. Öğrenci bir sözcük üzerinde on saniyeden fazla bir süre bekliyorsa, uygulayıcı bir sonraki kelimeyi göstermekte veya sunmaktadır. Bu gibi durumlarda uygulayıcı Kelime Tanıma Çizelgesi’ne öğrencinin kelimeyi okuyamadığını gösteren "bilmiyor" yazmakta ve ödün verilmemektedir.

6. Öğrencinin kelime tanıma düzeyi puanı, doğru okuduğu her kelime için $\sqrt{ }$ ile işaretlenmiş kelimelerin sayısını ifade etmektedir (Bader ve Pearce, 2013; Johns, 2016; Roe ve Burns, 2007; Shanker ve Cockrum, 2014; Silvaroli ve Wheelock, 2011; Woods ve Moe, 2011).

Öğrencilerin her bir listede yer alan 20 kelimeyi okudukları esnada, uygulayıcı sadece uygulayıcıların görebileceği belgeye okunan her kelime için notlar almaktadır. Öğrencinin okuduğu her kelime için Kelime Tanıma Çizelgesine doğru anlamına gelen $\sqrt{ }$ işareti konulmakta, hatalı okuduysa eğer kelime öğrencinin okuduğu şekilde yazılmaktadır. Hatalı okuduğu kelimeler öğrencinin okuduğu şekilde kaydedildikten sonra ne tür okuma hataları yaptığı değerlendirme aşamasında belirlenmektedir (Roe ve Burns, 2007, s. 18).

3 Ekim 2016 tarihinde A ilkokulu 1-E sinıfi, C ilkokulu 1-A sinıfı ve B ilkokulu 1-F sinıfı öğretmenleri 1. Seviye Grubunun ilk sesi olan "e" sesini vermeye başlamıştır. 10 Ekim 2016 tarihinde de B ilkokulu 1-B sınıfı öğretmeni 1. Seviye Grubunun ilk sesi olan "e" sesini vermiştir. "l", "a" ve " $n$ " sesleri de ilerleyen tarihlerde verildikten sonra 2-4 Kasım 2016 tarihleri arasında 1. Seviye listeleri uygulanmıştır. Uygulamalar okulun kütüphanesinde ve müdür yardımcısının odasında bire-bir araştırmacı-öğrenci şeklinde olmuştur. Araştırmacı sınıflara gidip öğrencileri tek tek uygulamanın yapıldı̆̆ı mekâna çağırıp onlara envanterdeki listeleri okutmuştur. Bunun araştırmaya faydası ise, araştırmacının uygulamalarını sessiz ve öğrenci ile baş başa kaldığı bir 
ortamda gerçekleştirmesidir. Uygulamadan önce uygulayıc öğrenciye süreç ve uygulama ile ilgili kısa bir bilgi vermiştir (Woods ve Moe, 2011).

29-30 Kasım 2016 tarihlerinde A ilkokulu 1-E sinıfinda, 2. Seviye kelime listeleri olan 5 liste uygulanmıştır. Bunu 30 Kasım-2 Aralık 2016 tarihleriyle B ilkokulu 1-F sınıfında, 2-7 Aralık 2016 tarihlerinin sabah saatlerinde B ilkokulu 1-B sınıfinda, öğleden sonraki saatlerde de C ilkokulu 1-A sınıfinda 2. Seviye listeleri uygulamaları bitmiştir. 3. Seviye kelime listeleri 13-20 Aralık 2016 tarihlerinde bütün sınıflarda uygulanmıştır. 3-4 Ocak 2017 tarihlerinde B ilkokulu 1F sınıfında 4. Seviye kelime listeleri olan 15 liste uygulanmaya başlanmış ve 10-11 Ocak 2017 tarihinde 15 liste de tamamlanmıştır. Bu sırada 11 Ocak 2017 tarihinde B ilkokulu 1-B sınıfının öğretmeni, 12 Ocak 2017 tarihinde de A ilkokulu 1-E sınıfının öğretmeni tüm sesleri bitirmiştir. 13 Ocak 2017 tarihinde sadece B ilkokulu 1-F sinıfinda 5. Seviye listelerinin 8 listesi uygulanmaya başlanmıştır. 18 Ocak 2017 tarihinde de C ilkokulu 1-A sınıfının öğretmeni tüm sesleri bitirmiştir. Böylece yarıyıl tatiline girmeden önce tüm sınıflarda sesler bitirilmiştir. 20 Ocak 2017 tarihinde okullar yarıyl tatiline girmiştir.

6 Şubat 2017'de yarıyıl tatilinin bitmesiyle birlikte okullar yeniden açılmış fakat öğrencilerin bir kısmının sesleri unutması sonucu genel tekrar yapmaları gerektiğini düşünen öğretmenlerle ortak bir karar alınmış ve uygulamalara ikinci hafta gidilmesine karar verilmiştir. 13-17 Şubat 2017 tarihlerinde sabahları B ilkokulu 1-B sınıfı ve B ilkokulu 1-F sınıfında, öğleden sonra da A ilkokulu 1-E sinıfi ve C ilkokulu 1-A sinıfinda 5. Seviye ve 6. Seviye listelerinin tamamı olan 31 liste okutulmuştur. Böylece "Kelime Tanıma Envanteri-1" de yer alan 64 liste tüm sınıflarda tamamlanmıştır. Öğretmenler bu sırada ses gruplarını tamamladıktan sonra dik temel yazıya geçmişler, öğrencilere pekiştirmeleri için dik temel yazı ile ilgili hem yazı hem de okuma ödevleri vermişlerdir. 20 Şubat- 1 Mart 2017 tarihlerinde tüm sinıflarda dik temel yazı kelime listeleri okutulmuş, "Kelime Tanıma Envanteri-2" de yer alan 34 liste tüm sınıflarda tamamlanmıştır. Sadece A ilkokulu 1-E sınıfında 1 kişi, C ilkokulu 1-A sınıfında 3 kişi hastalanıp okula gelememiş ve listelerde geri kalmıştır. $\mathrm{Bu}$ öğrencilerin listelerini tamamlamak için araştırmacı 3 Mart 2017 tarihinde yeniden okullarına gitmiş ve öğrencilerin listelerin tamamını okumalarını sağlamıştır.

\section{Bulgular}

$\mathrm{Bu}$ bölümde ilkokul birinci sınıf öğrencilerinin kelime tanıma düzeylerini ölçecek şekilde geliştirilen KTE-1 ve KTE-2 iyi bir ölçme aracı özellikleri taşıdığına ilişkin bulgular yorumlanarak verilmiştir.

\section{KTE-1 Tüm Kelime Tanıma Listelerine Ait Bulgular}

Aşağıda KTE-1 uygulamasında tüm kelime listelerinde birinci sınıf öğrencilerinin en çok doğru okudukları kelimeleri, bu kelimelerin türlerini, yapılan hata sayısını ve ne tür hatalar yaptıklarını gösteren Tablo 4 yer almaktadır.

Tablo 4.

KTE-1'de En Çok Doğru Okunan Kelimelere Ait Değerler

\begin{tabular}{|c|c|c|c|c|}
\hline Kelime Listeleri & Kelimeler & Kelime Türü & Hata Sayıs1 & Hata Türü \\
\hline \multirow{2}{*}{ 1. Seviye Kelime Listesi } & $\mathrm{Al}$ & İsim-Sifat-Fiil & 1 & Yerine Koyma \\
\hline & & & 1 & Öğretmenin Söylemesi \\
\hline 2. Seviye Kelime Listesi & Ali & İsim & 1 & Yerine Koyma \\
\hline 3. Seviye Kelime Listesi & İki & İsim-Sifat & 1 & Yerine Koyma \\
\hline \multirow{2}{*}{ 4. Seviye Kelime Listesi } & Dede & İsim & 1 & Çıkarma Yapma \\
\hline & Delik & İsim-Sifat & 1 & Ekleme Yapma \\
\hline \multirow{3}{*}{ 5. Seviye Kelime Listesi } & $\mathrm{Aç}$ & $\begin{array}{c}\text { Sifat-Zarf-Fiil } \\
\text { İsim }\end{array}$ & - & - \\
\hline & Ege & $\begin{aligned} \text { ISImI } \\
\text { Fiil }\end{aligned}$ & - & - \\
\hline & Yap & İsim & - & - \\
\hline
\end{tabular}




\begin{tabular}{lrllr} 
& Gelin & & - & \\
6. Seviye Kelime Listesi & Ev & İsim & 1 & Tersine Çevirme \\
& Fayda & İsim & 1 & Yerine Koyma \\
& Av & İsim & 1 & Yerine Koyma \\
\hline
\end{tabular}

Tablo 4'e göre KTE-1 uygulamasında tüm kelime listelerine ait elde edilen bulguların genel değerlendirilmesi yapıldığında en dikkat çeken bulgu; sadece 5. Seviye Listelerinde yer alan bazı kelimelerin okunmasında öğrencilerin tamamının hatasız okumasıdır. Diğer listelerde en fazla 1 hata ya da 2 hata ile okunan kelimeler yer almaktadır. Bu kelimeler öğrencilerin geçmiş yaşantılarında da en fazla kullandıkları ve Karadağ'a göre (2013) "Ege" kelimesinin özel isim olmasından kaynaklı listede yer almaması dışında diğer kelimeler "Aç", "Yapmak", "Gelin" ögrencilerin hedef kelime listelerinde yer alması gereken kelimelerdendir. En fazla bir hatanın yer aldığı diğer listelerde de en çok yerine koyma hata türünün yapıldığı görülmektedir. Kelime türlerinde ortak olan bulgu ise genelde kelimelerin isim olma özelliği göstermesidir. Buradan kelime türü ile hata türü arasında ilişki kurulursa eğer; bu ilişkinin isim kelime türü ile yerine koyma hatası arasında olacağı düşünülmektedir.

Aşağıda KTE-1 uygulamasında tüm kelime listelerinde birinci sınıf öğrencilerinin en çok yanlış okudukları kelimeleri, bu kelimelerin türlerini, yapılan hata sayısını ve ne tür hatalar yaptıklarını gösteren Tablo 5 yer almaktadır.

Tablo 5.

KTE-1'de En Çok Yanlış Okunan Kelimelere Ait Değerler

\begin{tabular}{lrrrr}
\hline Kelime Listeleri & Kelimeler & Kelime Türü & Hata Sayısı & Hata Türü \\
\hline 1. Seviye Kelime Listesi & Lala & İsim & 29 & Yerine Koyma \\
2. Seviye Kelime Listesi & Tabii & Sıfat-Zarf & 38 & Yerine Koyma \\
3. Seviye Kelime Listesi & Kask & İsim & 39 & Ekleme Yapma \\
4. Seviye Kelime Listesi & Komünikasyon & İsim & 46 & Yerine Koyma \\
5. Seviye Kelime Listesi & Gol & İsim & 34 & Yerine Koyma \\
6. Seviye Kelime Listesi & Blöf & İsim & 31 & Ekleme Yapma \\
\hline
\end{tabular}

Tablo 5'e bakıldığında en çok dikkat çeken bulgu 4. Seviye Kelime Listelerinde yer alan "Komünikasyon" kelimesini çalışma grubunda yer alan öğrencilerden yarısından fazlasının hatalı okumasıdır. Bu kelimenin okunuşunda çok fazla hata yapılmasının, diğer kelimelere göre hece sayısının fazla ve telaffuzunun da zor olmasından kaynaklandığını söyleyebiliriz. Kelimelerin ortak noktalarından bir tanesi de yabancı kökenli olmalarıdır. Listelerde yer alan kelimelerin okunuşunda hataların en fazla yerine koyma hata türüyle yapıldığ 1 bunu ekleme yapma hata türünün izlediği görülmektedir. Kelime türlerinde ortak olan bulgu ise "Tabii” kelimesi dışında diğerlerinin hepsinin isim olma özelliği göstermesidir. Buradan kelime türü ile hata türü arasında ilişki kurulursa eğer; tıpkı doğru okunan kelimelerdeki gibi bu ilişkinin isim kelime türü ile yerine koyma hatası arasında olacağı düşünülmektedir.

Listelerin okunma süreleri arasında bir ilişki kurulacak olunursa, listeler okundukça öğrencilerin okuma hızlarının da aynı oranda artma ya da azalma gösterdiği söylenemez. Bir diğer ifadeyle listeler ilerledikçe ve çoğaldıkça öğrenciler bazen hız kazanmıştır, bazen de hızlarını azaltmışlardır. En hızlı okunan liste 5. Seviye Listelerinden 1A listesinin 18 saniyede okunmasıdır. En yavaş okunan liste de 3. Seviye Listelerinden yine 1A listesinin 7 dakika 2 saniyede okunmasıdır. Burada dikkat çeken bulgu aslında en hızlı ve en yavaş okuyan öğrencilerin ilk üç seviye listelerinde aynı kişiler olmasıdır. Bir diğer ifadeyle listeleri en hızlı okuyan öğrencinin ve en yavaş okuyan öğrencinin aynı kişiler olmasıdır.

\section{KTE-2 Tüm kelime tanıma listelerine ait bulgular}


Aşağıda KTE-2 uygulamasında tüm kelime listelerinde birinci sınıf öğrencilerinin en çok doğru okudukları kelimeleri, bu kelimelerin türlerini, yapılan hata sayısını ve ne tür hatalar yaptıklarını gösteren Tablo 6 yer almaktadır.

Tablo 6.

KTE-2'de En Çok Doğru Okunan Kelimelere Ait Değerler

\begin{tabular}{lrrrr}
\hline Kelime Listeleri & Kelimeler & Kelime Türü & Hata Sayısı & Hata Türü \\
\hline & Su & İsim & - & - \\
& Nar & İsim & - & - \\
3. Seviye Kelime Listesi & Orta & İsim-Sifat & - & - \\
& Ankara & İsim & - & - \\
& Ok & İsim & - & - \\
& Sel & İsim & - & - \\
& Ön & İsim-Sıfat & - & - \\
& Sarı & İsim-Sıfat & - & - \\
4. Seviye Kelime Listesi & Yemek & İsim & - & - \\
& Kasım & İsim & - & - \\
& Ekmek & İsim & - & - \\
& Kuş & İsim & - & - \\
5. Seviye Kelime Listesi & Önce & Zarf & - & - \\
& Kitap & İsim & - & - \\
6. Seviye Kelime Listesi & Gül & İsim-Fiil & - & - \\
& Gaga & İsim & - & - \\
& İçinde & Zarf & - & - \\
\hline
\end{tabular}

Tablo 6'ya bakıldığında en çok dikkat çeken bulgu bu envanterde tüm seviye gruplarında bazı kelimelerin hatasız okunmasıdır. Bu kelimeler öğrencilerin geçmiş yaşantılarında da en fazla kullandıkları ve günlük konuşmalarında sık sık yer verdikleri kelimeler olduğu düşünülmektedir. Karadağ’a göre (2013) "Ankara" ve "Kasım" kelimelerinin özel isim olmalarından kaynaklı listede yer almaması dışında, "Nar", "Ok", "Gaga", "İçinde" kelimeleri hariç diğger kelimeler olan "Su", “Orta", "Sel”, “Ön", "Sarı", "Yemek", "Ekmek", "Kuş", "Önce”, “Kitap”, Gül” ve "Telefon" kelimeleri öğrencilerin hedef kelime listelerinde yer alması gereken kelimelerdendir (s. 156-166). Kelime türlerinde ortak olan bulgu ise genelde kelimelerin isim, isim-sıfat, isim-fiil olma özelliği göstermesidir.

Aşağıda KTE-2 uygulamasında tüm kelime listelerinde birinci sınıf öğrencilerinin en çok yanlış okudukları kelimeleri, bu kelimelerin türlerini, yapılan hata sayısını ve ne tür hatalar yaptıklarını gösteren Tablo 7 yer almaktadır.

Tablo 7.

KTE-2'de En Çok Yanlış Okunan Kelimelere Ait Değerler

\begin{tabular}{lrrrr}
\hline Kelime Listeleri & Kelimeler & Kelime Türü & Hata Sayıs1 & Hata Türü \\
\hline 3. Seviye Kelime Listesi & Tren & İsim & 39 & Ekleme Yapma \\
4. Seviye Kelime Listesi & Cisim & İsim & 19 & Yerine Koyma \\
5. Seviye Kelime Listesi & Plan & İsim & 29 & Ekleme Yapma \\
6. Seviye Kelime Listesi & Şoför & İsim & 18 & Yerine Koyma \\
\hline
\end{tabular}

Tablo 7'ye bakıldığında en çok dikkat çeken bulgunun 3. Seviye Kelime Listelerinde yer alan "Tren" kelimesini çalışma grubunda yer alan öğrencilerin yarısına yakınının hatalı okumasıdır. Bu kelimenin okunuşunda çok fazla hata yapılmasının tek heceli olmasından ve çocukların iki ünsüz harfin yan yana gelmesinde zorluk çektikleri için ekleme yapma ihtiyacı 
hissetmelerinden kaynaklandığını söyleyebiliriz. Kelimelerin ortak noktalarından bir tanesi de yabancı kökenli olmalarıdır. "Cisim" kelimesi Arapça kökenli, diğerleri de Fransızca kökenli kelimelerdir. Listelerde yer alan kelimelerin okunuşunda hataların en fazla ekleme yapma hata türüyle yapıldığı bunu yerine koyma hata türünün izlediği görülmektedir. Kelime türlerinde ortak olan bulgu ise en çok yanlış okunan kelimelerin isim olma özelliği göstermesidir. Buradan kelime türü ile hata türü arasında ilişki kurulursa bu ilişkinin isim kelime türü ile ekleme yapma hatası arasında olacağ1 düşünülmektedir.

Listelerin okunma süreleri arasında bir ilişki kurulacak olunursa listeler okundukça okuma hızları da aynı oranda artma ya da azalma gösterdiği söylenemez. Bir diğer ifadeyle listeler ilerledikçe ve çoğaldıkça öğrenciler bazen hız kazanmıştır, bazen de hızlarını azaltmışlardır. En hızlı okunan liste 3. Seviye Listelerinden 2. listenin 18 saniyede okunmasıdır. En yavaş okunan liste de 4. Seviye Listelerinden 11. listenin 3 dakikada okunmasıdır. Burada dikkat çeken bulgu aslında bitişik eğik yazıyla yazılmış listelere göre dik temel yazıyla yazılmış bu kelime listelerinin öğrenciler tarafından daha hızlı okunmasıdır. Bitişik eğik yazıyla yazılan KTE-1'de en hızlı okuyan öğrenci 18 saniyede, KTE-2'de ise en hızlı okuyan öğrenci 15 saniyede okumuştur. Yine bitişik eğik yazıyla yazılan KTE-1'de en yavaş okuyan öğrenci 7 dakika 2 saniyede, KTE-2'de ise en yavaş okuyan öğrenci 3 dakikada okumuştur.

Buna göre ölçme araçlarının geçerlik ve güvenirliğinin yüksek düzeyde olduğunu ortaya koymas1, hata türü ve kelime türü arasında yüksek düzeyde ilişki bulunması, kelimeyi doğru okuma ve okuma hızları arasında doğru orantı olması ve tüm bu özelliklerin her iki envanterde de tutarlılık göstermesi envanterlerin iyi bir ölçme aracı niteliğini sağladığını göstermektedir.

\section{Tartışma ve Sonuç}

$\mathrm{Bu}$ çalı̧̧mada öğrencilerin kelime tanıma düzeylerinin belirlenmesi ve okuma parçalarının öğrencilerin düzeylerine göre seçilmesi açısından katkı sağlayacak geçerli ve güvenilir bir aracın geliştirilmesi ve bu aracın uygulanabilirliğini ortaya koyması amaçlanmıştır. Buna göre; ilkokul birinci sınıf öğrencilerinin kelime tanıma düzeylerini ölçecek şekilde geliştirilen KTE-1 ve KTE2'nin bir ölçme aracı özellikleri taşıdığına ilişkin bulgulara göre elde edilen sonuçlar sıralanmıştır. Geliştirilen envanterlerin uygulama yapılmadan önce ölçme araçlarında bulunması gereken niteliklerden geçerlik ve güvenirliğine bakılmıştır. Kelime tanıma düzeylerinin belirlenmesinin amaçlandığı çalışmada bir bakıma başarı değerlendirmesi söz konusu olduğu için öncelikle içerik geçerliğine bakılmıştır. İçerik geçerliği için; seçilen kelimelerin öğrencilerin yaşına, bilgi düzeyine ve sınıf seviyesine uygunluğuna, listelerde yer alan sözcük çeşitliliğinin benzerliğine (orantılı isim, sıfat, fiil kullanımı gibi...), kelimelerin basitten karmaşığa doğru sıralanmasına ve değerlendirme formunun düzenlenmesine uzman kişilerin görüşleri alınarak bakılmıştır. Araştırmanın iç geçerliğine olası etki eden katılımcılara, veri toplama araçlarına ve mekâna bağlı olarak ortaya çıkabilecek tehditlere yönelik önlemler alınmıştır. Araştırmaya katılan öğrencilere çeşitli değişkenler açısından benzerlikler ortaya koymak adına "Öğrenci Bilgi Formu" uygulanmış, katılımcı kaybı olmaması adına önlemler alınmış bazı öğrenciler belirlenerek araştırmanın kapsamı dışında tutulmuştur. Öğrenciler üzerinde beklenti etkisi yaratılmış, tüm katılımcılara aynı ölçme aracı, aynı zaman diliminde, eşit sürede ve aynı kişiler tarafından uygulanarak veri toplama araçlarından kaynaklanabilecek tehditlerin önüne geçilmeye çalışılmıştır. Mekâna bağlı olarak ortaya çıkabilecek iç geçerlik tehditlerini engelleyebilmek için tüm sinıflarda veriler aynı ortamda toplanmıştır.

Araştırmanın güvenirliğini arttırmak için araştırmanın varsayımları, kısıtlamaları, veri toplama araçları, veri toplama araçlarının uygulanışı, katılımcılarla olan ilişki, öğretmenlerle olan ilişki ve araştırmaya dair tüm adımlar ayrıntılı şekilde açıklanmıştır. Veri toplama sırasında kelime listeleri birkaç araştırmacı tarafından toplanması ve hatalı okumalardaki belirgin olmayan yanlışların analizinde uzmanlara danışılıp ortak bir karar sonucu yanlışın ne tür bir yanlış olduğunun belirlenmesi de değerlendiriciler arası güvenirliğe örnek olarak verilebilmektedir. İç tutarlıklarının güvenirliğini ortaya koymak için KTE-1 ve KTE-2'deki tüm listelerin Cronbach Alpha güvenirlik katsayısına bakılmış ve katsayının .70'den daha büyük olduğu görülmüştür. 
Geçerliği ve güvenirliği sağlanan ve bir ölçme aracı olma özelliği gösterdiği sonucuna ulaşılan KTE-1ve KTE-2 uygulanan birinci sınıf öğrencilerinin en çok doğru okudukları kelimeler, doğru okuyan kişi sayısı, en çok yanlış okudukları kelimeler, yanlış okuyan kişi sayısı, okuma süreleri gibi bulgulardan elde edilen sonuçlar şu şekilde sıralanmıştır: Bu çalışmada en çok doğru okunan kelimelerin arasında "Dede", "Gaga" gibi tekrarlı seslerden oluşmuş kelimeler olduğu dikkat çekmektedir. İlk çocukluk günlerinden itibaren öğrenciler, tekrarlı seslerden oluşan kelimeleri söylemekten çok hoşlanırlar. Dolayısıyla bu kelimelerin en çok doğru okunan kelimeler arasında yer alması beklenen sonuçlar arasındadır. Okulu çağrıştıran "Okul", "Sıra", "Kitap", "Silgi", "Ödev", "Başarılı" gibi kelimeler de öğrencilerin en çok doğru okudukları kelimeler arasındadır. Özkan (2012), çalışmasının örnekleminde yer alan öğrencilerin toplam 6 temada yer alan 193 sözcük arasında doğru kullanım oranı en fazla olan sözcüklerin: "Atatürk, gözü tutmak, misafir, fikir, vakit, konser, kıyı, yakasına yapışmak, çevresine bakmak, otobüs, yurt, empati, gelenek, zaman, teftiş, fert, orkestra, köle, tasarruf, vicdan azabı duymak" olduğunu belirtmektedir. $\mathrm{Bu}$ çalışmada geçen kelimelerle bizim araştırmamızda geçen "Atatürk" ve "Otobüs" kelimelerinin ortak kelimeler olduğu görülmektedir. Temur'un (2006) ve Çetinkaya'nın (2011) araştırmalarında ortaya koydukları gibi bu araştırmada da en en çok doğru okunan kelimelerin büyük çoğunluğunun isimlerden oluştuğu, bunu sıfat, fiil, zarf ve zamirlerin izlediği görülmektedir. Araştırmacılar (Çıplak, 2005; Yalçın, 2005; Yersüren, 2009; Karahan, 2007) kelimeleri temel türlerine göre inceledikleri çalışmalarında, isimlerin doğal olarak fiillere oranla daha fazla kullanıldığını belirlemişlerdir. Bu konuda Çıplak (2005); "Bütün dillerdeki yazılı ve sözlü anlatımlarda isimlerin fiillerden fazla kullanılması doğaldır. Çünkü bir dildeki fiillerin sayısının sınırlı" olduğunu belirtmektedir. Bu çalışmada yer alan kelimelerin anlam, yapı, tür, görev ve köken açısından analizleri dikkate alındığında öğrencilerin somut ve gerçek anlam taşıyan, basit yapıll, Türkçe ve isim kökenli kelimeleri daha iyi tanıdıkları görülmüștür. Bu çalışmanın bulgularından elde edilen sonuçlara göre "Mavi", "Sarı" gibi renkler; "Bir", "İki” gibi sayılar; "El”, "Göz" gibi organlar; "Kızgın", "Üzgün", "Mutlu” gibi duygu ifade şekilleri; “Ali”, "Mustafa" gibi Türkiye İstatistik Kurumu'nun (TÜIIK, 2017) verilerine göre en sık duyulan erkekkadın isimleri; "Tavuk", "Kedi", "Kuzu" gibi hayvan isimleri; "Meyve", "Ekmek", "Et" gibi yemek isimleri öğrencilerin en çok doğru okudukları kelime türlerine örneklerdir. Böylece doğru okunan kelimelerin çocuğun günlük yaşamından elde edilebilecek ve sıklıkla duyduğu kelimelerden olduğu görülmektedir.

Bu çalışmada en çok yanlış okunan kelimeler arasında Türkçe kökenli kelimelerin dışında Fransızca kökenli kelimelerin yer aldığı görülmektedir. Yalçın (2005), çalışmasında ilköğretim 1 ve 5. sınıf Türkçe ders kitabı metinlerinde yer alan sözcüklerin çoğunluğunu Türkçe kökenli sözcüklerin oluşturduğunu, geri kalan kısmını ise genellikle Arapça, Farsça ve Fransızca kökenli sözcüklerin oluşturduğunu belirtmiştir. Genellikle en çok yanlış okunan kelimelerin iki sessiz harfin yan yana geldiği kelimeler olduğunu görülmektedir. Öğrenciler bu kelimeleri okurken iki sessiz harfin arasına bir sesli harf getirerek be bunu baskın bir şekilde okuyarak en çok ekleme hatasını yapmışlardır. Bir diğer bulgu da öğrenciler için anlamlı olmayan soyut kelimelerin en çok yanlış okunan kelimeler arasında çoğunlukta olmasıdır. Öğrencilerin soyut anlam içeren sözcükleri yeterince tanımadıklarını gösteren bu sonuç, Aköz ve Toptaş'ın (2009) çalışmaları ile paralellik göstermektedir. Korkmaz da (2007), Türkçe ders kitaplarında yer alan metinlerde soyut anlam içeren sözcüklerin fazlalığından söz etmektedir. Ayrıca Genç (2010), özellikle 1, 2 ve 3. sınıf ders kitaplarında daha net ve somut sözcüklerin kullanılması gerektiğini vurgulamaktadır.

KTE-1 kelime listelerinin okunma süreleri arasında en hızlı okuma sürelerinde seviyeler ilerledikçe gelişme olduğu; en yavaş okuma sürelerinde seviyeler ilerledikçe gerileme olduğu söylenemez. Üçüncü seviye kelime listelerinden birini okuyan öğrencinin birinci kelime listesini okuyan öğrenciden daha yavaş; beşinci seviye kelime listelerinden birini okuyan öğrencinin altıncı kelime listelerinden birini okuyan öğrenciden daha hızlı okuduğu sonucu elde edilmiştir. Dik temel yazıyla hazırlanan KTE-2 kelime listelerinin okunma süreleri arasında da en hızlı okuma sürelerinde seviyeler ilerledikçe gelişme olduğu; en yavaş okuma sürelerinde seviyeler ilerledikçe gerileme olduğu söylenemez. Dördüncü seviye kelime listelerinden birini okuyan öğrencinin üçüncü kelime listesini okuyan öğrenciden daha yavaş; üçüncü seviye kelime 
listelerinden birini okuyan öğrencinin dördüncü kelime listelerinden birini okuyan öğrenciden daha hızlı okuduğu sonucu elde edilmiştir.

Araştırma sonunda, geliştirilen KTE-1 ve KTE-2'nin birinci sınıf öğrencilerinin kelime tanıma düzeylerini iyi bir ölçme aracı niteliklerini taşıyacak şekilde ölçtüğü sonucuna ulaşılmıştır. KTE-1 ve KTE-2, 2016-2017 Eğitim-Öğretim yılında Ankara iline bağlı Yenimahalle ilçesinde yer alan 3 ilkokulun 4 birinci sınıfında eğitim gören 85 öğrenciye uygulanmasıyla sınırlıdır. Elde edilen bulguların genellenebilirliği için benzer çalışmaların daha büyük çalışma gruplarıyla yapılması gerektiğinden hazırlanan KTE-1 ve KTE-2 farklı çalışma grubuna da uygulanabilir. Farklı çalışma grubunun kelime tanıma düzeylerinin belirlenmesi yoluyla karşılaştırmalı araştırmalar yapılabilir.

\section{Etik Kurul Onay Bilgileri}

Çalışma; Hacettepe Üniversitesi Etik Komisyonunun 26 Temmuz 2016 tarihinde yapmış olduğu toplantıda incelenmiş, 35853172/433-2359 sayılı yazısıyla etik açıdan uygun bulunmuştur.

Araştırma İzni talebi, Ankara Valiliği Milli Eğitim Müdürlüğü’nün 21 Eylül 2016 tarihli toplantısında incelenmiş, 14588481-605.99-E.9995784 sayılı yazısıyla Milli Eğitim Müdürlüğünce uygun görülmüş, araştırmanın yapılacağı İlçe Milli Eğitim Müdürlüğüne bilgi verilmiş̧tir.

\section{Kaynaklar}

Aköz, Y. ve Toptaş, B. (2009, Mayıs). İlköğretim 4. sinıf ögrencilerinin Türkçe dersinde ögrendiği kelimelerin anlamlarının karşılığının zihinsel olarak kavrama düzeylerinin incelenmesi [Öz]. VIII. Ulusal Sınıf Öğretmenliği Eğitimi Sempozyumu'nda sunulan bildiri. Eskişehir Osmangazi Üniversitesi Eğitim Fakültesi, Eskişehir.

Akyol, H. (1998). Kelime tanıma ve okumaya etkisi. VII. Ulusal Eğitim Bilimleri Sempozyumu Bildirileri, Konya: Selçuk Üniversitesi Yayınları 1, içinde (ss. 677-684).

Akyol, H. (2012). Türkçe ilk okuma yazma öğretimi. Ankara: Pegem Akademi Yayınları.

Akyol, H., Yıldırım, K., Ateş, S., Çetinkaya, Ç. ve Rasinski, T. V. (2014). Okumayı değerlendirme. Ankara: Pegem Akademi Yayınları.

Avşar Tuncay, A. (2017). İlkokul birinci sınıf öğrencilerine yönelik bir kelime tanıma envanteri tasarım ve geliştirme çalışması (Yayımlanmamış doktora tezi). Hacettepe Üniversitesi, Eğitim Bilimleri Enstitüsü, Ankara.

Bader, L. A. ve Pearce, D. L. (2013). Bader reading and language inventory (7thed.). New Jersey: Pearson Education.

Büyüköztürk, Ş. (2007). Sosyal bilimler için veri analizi el kitabı. Ankara: Pegem A Yayıncılık.

Büyüköztürk, Ş., Kılıç-Çakmak, E., Akgün, Ö. E., Karadeniz, Ş. ve Demirel, F. (2016). Bilimsel araştırma yöntemleri (20. Bask1). Ankara: Pegem A Yayıncılık.

Cooter, R. B. ve Flynt, E. S. (1996). Teaching reading in the content areas: Developing content literacy for all students. New Jersey: Prentice-Hall, Inc.

Çetinkaya, Ç. (2011). İlköğretim 4 ve 5. sınıf ögrencilerinin kelime kullanım sılklkları üzerine bir araştırma (Yayımlanmamış doktora tezi). Gazi Üniversitesi, Eğitim Bilimleri Enstitüsü, Ankara.

Çıplak, M. (2005). Uşak merkez ilköğretim 5., 8. ve 11. sınıfların yazılı kelime hazinesinin belirlenmesi (Yayımlanmamış yüksek lisans tezi). Afyon Kocatepe Üniversitesi Sosyal Bilimler Enstitüsü, Afyonkarahisar.

Delimehmet Dada, Ş. (2017). Öğrenme güçlüğü olan ve olmayan ögrencilerin sözcük bilgisi ve okuduğunu anlama becerileri arasındaki iliş̧ki (Yayımlanmamış yüksek lisans tezi). Ankara Üniversitesi, Eğitim Bilimleri Enstitüsü, Ankara.

Design-Based Research Collective. (2003). Design-based research: An emerging paradigm for educational inquiry. Educational Researcher, 32(1), 5-8.

Garnett, K. (2011). Fluency in learning to read: Conceptions, misconceptions, learning disabilities, and instructional moves. J. R. Birsh (Yay. haz.), Multisensory teaching of basic language skills içinde (ss. 293-320). Baltimore, MD: Brookes Publishing. 
Genç, B. (2010). Türkçe dersinde öğrenilen yeni sözcüklerin yazılı anlatımda kullanım durumu (Yayımlanmamış yükssek lisans tezi). Eskişehir Osmangazi Üniversitesi, Sosyal Bilimler Enstitüsü, Eskişehir.

Genç, T. (2016). İşitme engelli kaynaştırma öğrencilerinin okuma becerilerinin formel olmayan okuma envanteri ile değerlendirilmesi (Yayımlanmamış yüksek lisans tezi). Anadolu Üniversitesi, Eğitim Bilimleri Enstitüsü, Eskişehir.

Goodman, K. (1967). Reading: A psycholinguistic guessing game. Journal of the Reading Specialist, 6, 126-135.

Göçer. A. (2013). İlköğretimde Türkçe öğretimi. A. Kırkkılıç ve H. Akyol (Yay. haz.), Türkçe ögretiminde ölçme ve değerlendirme içinde (ss. 477-519). Ankara: Pegem Akademi Yayınları.

Göçmenler, H. (2016). Koklear implant kullanan çocuklarda okuma ve yazma becerilerinin değerlendirilmesi (Yayımlanmamış yükssek lisans tezi). Marmara Üniversitesi, Sağlık Bilimleri Enstitüsü, İstanbul.

Güneş, F. (2013). Türkçe öğretimi yaklaşımlar ve modeller. Ankara: Pegem Akademi Yayınları.

Harris, A. J. ve Sipay, E. R. (1990). How to increase reading ability: A guide to developmental \& remedial methods. (9th ed.). London: Longman.

Hart, B. ve Risley, T. (2003). The early catastrophe. American Educator: Spring.

Johns, J. L. (2016). The basic reading inventory (12thed.). Dubuque, IA: Kendall/Hunt.

Johnson, A. P. (2014). Eylem araştırması el kitabı. (Yıldız U. ve Meltem Ö. A., Çev.) Ankara: Anı Yayıncilik.

Karadağ, Ö. (2005). Illköğretim birinci kademe ögrencilerinin kelime hazinesi üzerine bir araştırma (Yayımlanmamış doktora tezi). Gazi Üniversitesi, Eğitim Bilimleri Enstitüsü: Ankara.

Karadağ, Ö. (2013). Kelime ögretimi. İstanbul: Kriter Yayınevi.

Karahan, F. (2007). Language attitudes of Turkish students towards the English language and its use in Turkish context. Journal of Arts and Sciences, 7, 73-87.

Karasu, H. P. (2011). İşitme engelli öğrenciler ve normal işiten öğrencilerin okuma becerilerinin formel olmayan okuma envanteri ile değerlendirilmesi (Yayımlanmamış doktora tezi), Anadolu Üniversitesi Eğitim Bilimleri Enstitüsü, Eskişehir.

Karasu, H. P., Girgin, Ü. ve Uzuner, Y. (2011). Okuma becerilerini değerlendirmede formel olmayan okuma envanterlerinin kullanımı. Ĕgitim Teknolojisi Kuram ve Uygulama, 1(1), 108-124.

Kırcaali-İftar, G. (1999). Sosyal bilimlerde araştırma yöntemleri. A. A. Bir (Yay. haz.) Ölçme içinde (s. 13-17). Eskişehir: Anadolu Üniversitesi Yayınları, 1081.

Kirk, J. ve Miller, M. L. (1986). Qualitative research methods: Reliability and validity in qualitative research. Newbury Park, CA: SAGE Publications, Inc. doi: $10.4135 / 9781412985659$.

Koç, E. (2016). Nitel araştırmalarda geçerlik ve güvenirlik. M. Yaşar Özden ve L. Durdu (Yay. haz.). Eğitimde üretim tabanlı çalışmalar için nitel araştırma yöntemleri içinde (ss. 149165). Ankara: Anı Yayıncılık.

Korkmaz, Z. (2007). Türkiye Türkçesi grameri şekil bilgisi (2. Baskı). Ankara: Türk Dil Kurumu Yayınları.

Kretschmer, R. R. ve Kretschmer, L. W. (1978). Language development and intervention with hearing impaired. Baltimore: University Park Press.

Lexile (2017). Lexile ölçüsü. Erişim Tarihi: 26 Kasım 2017, Erişim adresi: https://lexile-websitemedia2011091601.s3.amazonaws.com/cms_page_media/135/What\%20does\%20the\% 20Lexile\%20Measure\%20Mean.pdf

McKenney, S. ve Reeves, T. C. (2013). Handbook of research on educational communications technology. J. Michael Spector, M. David Merrill, Jan Elen, M. ve J. Bishop (Yay. Haz.), Educational Design Research içinde (ss. 131-160). New York: Springer.

McLoughlin, J. A. ve Lewis, R. B. (2004). Özel gereksinimli öğrencilerin ölçümlenmesi (F. Gencer, Çev.) Ankara: Gündüz Eğitim ve Yayıncılık. 
MEB. (2009). İlköğretim Türkçe dersi öğretim programı ve kılavuzu (1-5. Sinıflar). Ankara: Devlet Kitapları Müdürlüğ̈ Basım Evi.

Monti, D. A. (2003). Informing instruction: Prerequisite for success. The New England Reading Association Journal, 39, 9-12.

Mutlu, N. (2016). Tasarım ve geliştirme araştırma modeli. M. Yaşar Özden ve L. Durdu (Yay. haz.). Ë̆itimde üretim tabanlı çalışmalar için nitel araştırma yöntemleri içinde (ss. 4970). Ankara: Anı Yayıncilık.

Özden, M. Y. ve Durdu, L. (2016). Eğitimde üretim tabanlı çalışmalar için nitel araştırma yöntemleri. Ankara: Anı Yayınc1lik.

Özkan, E. (2012). İlköğretim 8. sinıf Türkçe ders kitaplarında ögrencilere kazandırılması hedeflenen sözcüklerin öğretimi ve iç sözlük ilişkisi (Yayımlanmamış yüksek lisans tezi). Mersin Üniversitesi, Eğitim Bilimleri Enstitüsü, Mersin.

Paris, S. G. ve Carpenter, R. D. (2003). FAQs about IRIs. Reading Teacher, 56(6), 578-560.

Pray, M. L. ve Ross, R. (1969). The graded word list: Quick gauge of reading ability. Journal of Reading, 12(4), 305-307.

Rayner, K., Foorman, B. R., Perfetti, C. A., Pesetsky, D. ve Seidenberg, M. S. (2001). How psychological science informs the teaching of reading. Psychological Science in the Public Interest, 2, 31-74.

Richey, R. C. ve Klein, J. D. (2008). Research on design and development. J. M. Spector, M. D. Merrill, J. van Merrienboer ve M. P. Driscoll (Yay. haz.), Handbook of research for educational communications and technology içinde (ss. 748-757). Mahwah, NJ: Lawrence Erlbaum Associates Publishers.

Richek, M. A., Caldwell, J. S., Jennings, J. H. ve Lerner, J. W. (2002). Reading problems: Assessment and teaching strategies (4th ed.). Boston: Allyn and Bacon.

Roe, B. D. ve Burns, P. C. (2007). Informal Reading Inventory. Preprimer to twelfth grade $\left(7_{\text {th }}\right.$ edition). Boston, New York: Houghton Mifflin Company.

Silvaroli, N. J. ve Wheelock, W. H. (2011). Classroom reading inventory (12thed.). Boston, MA: McGraw-Hill.

Shanker, J. L. ve Cockrum, W.A. (2014). Ekwall/Shanker reading inventory (6thed.). Boston, MA: Allyn \& Bacon.

Snow, C. E., Burns, M. S. ve Griffin, P. (Yay. haz.). (1998). Preventing reading difficulties in young children. Washington, DC: National Academy Press.

Temur, T. (2006). Illköğretim 4 ve 5. sinı öğrencilerinin yazı dilindeki kelime hazinelerinin bazı değişkenler açısından incelenmesi (Yayımlanmamış doktora tezi). Gazi Üniversitesi Eğitim Bilimleri Enstitüsü, Ankara.

Thiagarajan, S., Semmel, D. S. ve Semmel, M. I. (1974). Instructional development for training teachers of exceptional children: A Sourcebook. University of Minnesota: Leadership Training Institute/Special Education.

Thorndike, E. L. ve Lorge, I. (1944). The teacher's word book of 30,000 words. New York: Teachers College, Columbia University.

Torgesen, J. K. (1986). Computers and cognition in reading: A focus on decoding fluency. Exceptional Children, 53, 157-162.

TÜIKK. (2017). http://www.tuik.gov.tr/PreTablo.do?alt_id=1059 Erişim Tarihi: 28.09.2017

Uzuner, Y. (2008). İlk okuma yazma öğretiminde ölçme değerlendirme. G. Can (Yay. haz.). İlk okuma ve yazma ögretimi içinde (ss. 209-237). Eskişehir: Anadolu Üniversitesi Yayınları.

Woods, M. L. ve Moe, A. J. (2011). Analytical reading inventory: Comprehensive standardsbased assessment for all students including gifted and remedial (9thed.). Boston, MA: Pearson Education.

Yalçın, S. K. (2005). İlköğretim 1. ve 5. sınıf Türkçe ders kitaplarındaki sözvarlığı unsurlarının eğitsel açıdan değerlendirilmesi (Yayımlanmamış yüksek lisans tezi). Fırat Üniversitesi, Sosyal Bilimler Enstitüsü, Elazı̆̆.

Yersüren, N. (2009). Türk dil bilgisinde kelime türleri (ad ve ad soylu kelimeler) (Yayımlanmamış yüksek lisans tezi). Sakarya Üniversitesi, Sosyal Bilimler Enstitüsü, Sakarya. 


\section{Extended Abstract}

\section{Introduction}

Humans communicate through words and they maintain their comprehension and description activities thanks to words. Word recognition activities such as word comprehension and description which happen orally in the earlier years of life happen through listening and speaking. When school life begins, word comprehension and description activities are maintained through reading and writing in addition to listening and speaking. Assessment was needed to become aware of our level of reading and comprehension, to identify our mistakes effectively and to correct them, and thus alternative assessment instruments beside traditional instruments were used for such purposes (Akyol, 2012; Akyol, Yıldırım, Ateş, Çetinkaya \& Rasinski, 2014; Göçer, 2013; Karasu, Girgin \& Uzuner, 2011). Formal and informal assessment instruments can be used in evaluating reading as in the educational measurement and evaluation approaches to other domains of skill (Karasu, 2011, p. 20). Formal and informal measurement instruments are recommended to be used in combination to be able to evaluate the product and the process to monitor the progress in students' reading skill. Such evaluation enabling teachers to evaluate their students in depth as readers and to determine their weaknesses and strengths in reading easily can contain evaluation instruments such as criterion-referenced tests, observations, interviews, selfevaluation, product files and informal reading inventory (Cooter \& Flynt, 1996; Karasu, 2011; McLoughlin \& Lewis, 2004; Uzuner, 2008).

Reading inventory has been used as an evaluation instrument in reading assessment in Turkey (Akyol et al., 2014; Delimehmet Dada, 2017; Genç, 2016; Göçmenler, 2016; Karasu, 2011). The factor influential in students' reading comprehension is word recognition in evaluating reading. If students can recognise the words in a text, reading will be meaningful for students. Therefore, it would be better to give students Word Recognition Inventory (WRI) in which their word recognition is evaluated before giving them reading inventory in which their reading is evaluated. WRI is an informal assessment instrument of word lists which is given to determine and evaluate students' word recognition skill. Prior to developing the WRI-1 and WRI-2- which were developed by the researcher to determine students' levels of word recognition- word recognition lists included in the reading inventories used in other countries were analysed and the properties of the words included in the inventories, the criteria for determining the words and the properties to be considered in evaluation and marking were set. After that, words were derived from 6 levels of vocal groups and they were included in WRI-1. The words appearing in Turkish language, Life Science and mathematics course books were examined and they were included in WRI-2.

\section{Method}

This study uses Type 1 development research of design and development research model to develop an instrument to determine students' word recognition levels and to exhibit the applicability of the instrument. Research in which new products, instruments, models and processes are developed and in which the developed products are tested and their feasibility, effectiveness and efficiency are demonstrated is called "design and development research" (Richey \& Klein, 2008; as cited in Büyüköztürk, Kılıç-Çakmak, Akgün, Karadeniz \& Demirel (2016).

The study group was composed of 85 primary school students who were the first graders in three different state schools in Yenimahalle district of Ankara who were chosen in convenience sampling method. According to the demographic properties of the students, 44 of them $(51.8 \%)$ were female while 41 of them (48.2\%) were male. The WRI- 1 and WRI-2, which were developed by the researcher to determine students' word recognition levels, and word recognition chart were used as the data collection tools. WRI-1, which was written in italics, contained 64 lists each of which had 20 words and WRI-2, which was written in non-italic letters, contained 34 lists each of which had 20 words; and thus the inventories contained 98 lists in total. The word lists in the inventories were arranged in the way that each list is on a page and the font size for the words 
was 20. The words in the WRIs were given in stem/ infinitive form, care was taken to have words suitable to students' age, knowledge level and grade level, the words were chosen from the 6 levels of vocal groups and from textbooks, they were ordered according to the number of syllables and number of letters in them and they were from simple to complex, similar variation of words (such as nouns, verbs, adjectives) were given and each list contained 20 words. Word recognition charts are the measurement instruments designed in a way that practitioners can see but students cannot see, unlike inventories. The words students read correctly are recorded with the symbol " $\checkmark$ ", the words they read incorrectly are recorded as they read the words in word recognition charts. The reading errors students make are incorrect pronunciation, replacement, addition, deletion, reversing, repetition and teachers' correction.

Content necessity was checked for the suitability of the words in WRI-1 and WRI-2 for students and precautions were taken against the factors probable to affect internal and external validity. Reliability coefficients of WRI-1 and WRI-2 were calculated to show the reliability of internal consistency, and Cronbach's Alpha reliability coefficient was found to be .986 for all the lists of WRI-1 and .970 for all the lists of WRI-2. A group was chosen and the pilot scheme was done with the group to test the operability of the inventory. Following the pilot scheme, feedback was obtained from teachers and experts for the applicability of the research, and the necessary arrangements were made in the words in the inventories.

\section{Conclusions and Discussion}

This paper aimed to develop a valid and reliable instrument which would contribute to determining students' word recognition levels and to selecting the reading texts according to students' levels and to demonstrate the applicability of the instrument. The results obtained for the WRI-1 and WRI-2 are listed below. The results coming from the findings such as the words that the first graders to whom the WRI-1 and WRI-2 were applied read correctly most often, the number of students reading correctly, the words they read incorrectly most often, the number of students reading incorrectly and the length of time for reading are listed as in the following: the words which were read correctly most of the time were the words such as "dede" (grandfather) and "gaga" (beak) -which contained repeated sounds-. Children like saying words of repeated sounds beginning with their early childhood days. Thus, it was an expected result for them to read such words most correctly. Such words as "okul" (school), "kitap" (book), "ödev" (homework) and "başarıl1" (successful) -which associated school- were also the words students read correctly most often. Considering the analysis of words in this study in terms of meaning, structure, type, function and origin; it was found that students recognised words with concrete meaning and literal meaning, simple words and words which are Turkish in origin and words which are nouns better. The results obtained showed that colour words such as "mavi" (blue) and "sarı" (yellow); numbers such as "bir" (one) and "iki" (two); names of organs such as "el" (hand) and "göz" (eye); names of feelings such as "kızgın" (angry), "sad" (üzgün) and "mutlu" (happy); most frequently used names such as "Ali" and "Mustafa"; names of animals such as "tavuk" (hen), "kedi" (cat) and "kuzu" (lamb) and names of food such as "meyve" (fruit), "ekmek" (bread) and "et" (meat) were the examples for the students most often read correctly. Thus, it is clear that the words that are read correctly most often are the words they hear frequently in daily life.

The words read incorrectly most often included words borrowed from French language. The words that were most often read incorrectly were usually the words having two successive consonants. While reading such words the students put a vowel sound between the two consonants and thus, they made the mistake of addition. Another finding demonstrated that the words that students found meaningless were dominantly among the abstract words that they most often read incorrectly.

It cannot be said that there is improvement in length of time in reading the word lists in WRI- 1 and in WRI-2 in parallel to the progress in levels. Thus, it was found that students reading one of the level three word lists were slower than students reading one of the level one lists, and students reading one of the level five word lists were faster than students reading one of the level six word lists. It was concluded that the WRI-1 and WRI-2 measured the first graders' levels of 
word recognition in the way that a good measurement tool could measure. The WRI-1 and WRI2 were restricted to application with 85 primary school students who were the first graders in four first grade classes in three schools in Yenimahalle district of Ankara. WRI-1 and WRI-2 can be applied to different study groups since similar studies need to be conducted with larger study groups for the generalisability of the findings. Comparative studies can be performed by determining the word recognition levels of differing study groups. 